\title{
rem \\ Old Things New View: Ascorbic Acid Protects the Brain in Neurodegenerative Disorders
}

\author{
Adriana Covarrubias-Pinto ${ }^{1,2}$, Aníbal Ignacio Acuña ${ }^{1,2}$, Felipe Andrés Beltrán ${ }^{1,2}$, \\ Leandro Torres-Díaz ${ }^{1,2}$ and Maite Aintzane Castro ${ }^{1,2, *}$
}

Received: 22 July 2015; Accepted: 14 October 2015; Published: 27 November 2015

Academic Editor: Guido Haenen

1 Instituto de Bioquímica y Microbiología, Facultad de Ciencias, Universidad Austral de Chile, Valdivia 5090000, Chile; adriana.covarrubias@postgrado.uach.cl (A.C.-P.); aacuna.sanmartin@alumnos.uach.cl (A.I.A.); felipe.beltran@alumnos.uach.cl (F.A.B.); leandro.torres@postgrado.uach.cl (L.T-D.)

2 Center for Interdisciplinary Studies on the Nervous system (CISNe), Universidad Austral de Chile, Casilla 547, Valdivia 5090000, Chile

* Correspondence: macastro@uach.cl; Tel.: +56-63-221-332

\begin{abstract}
Ascorbic acid is a key antioxidant of the Central Nervous System (CNS). Under brain activity, ascorbic acid is released from glial reservoirs to the synaptic cleft, where it is taken up by neurons. In neurons, ascorbic acid scavenges reactive oxygen species (ROS) generated during synaptic activity and neuronal metabolism where it is then oxidized to dehydroascorbic acid and released into the extracellular space, where it can be recycled by astrocytes. Other intrinsic properties of ascorbic acid, beyond acting as an antioxidant, are important in its role as a key molecule of the CNS. Ascorbic acid can switch neuronal metabolism from glucose consumption to uptake and use of lactate as a metabolic substrate to sustain synaptic activity. Multiple evidence links oxidative stress with neurodegeneration, positioning redox imbalance and ROS as a cause of neurodegeneration. In this review, we focus on ascorbic acid homeostasis, its functions, how it is used by neurons and recycled to ensure antioxidant supply during synaptic activity and how this antioxidant is dysregulated in neurodegenerative disorders.
\end{abstract}

Keywords: oxidative stress; brain energy metabolism

\section{Introduction}

Ascorbic acid, the reduced form of vitamin $C$, is an essential metabolite for a variety of organisms. It is present in multiple fruits and vegetables [1] and is also synthesized from glucose in the liver of many mammalian species, allowing the maintenance of physiological levels. However, higher primates, including humans, lack the functional enzyme for the final step of synthesis, rendering them dependent on exogenous sources of ascorbic acid [2,3]. This dietary dependence led to its categorization as a vitamin upon the discovery that its deficiency caused scurvy. Ascorbic acid is an important antioxidant with multiple cellular functions. It plays a role in detoxification processes [4-6], participates as an enzymatic cofactor [7-9] modulates synaptic activity and neuronal metabolism [5,10-12], among other functions.

Ascorbic acid is concentrated in the brain [13]. The brain is responsible for the $25 \%$ of total body glucose utilization $[14,15]$. Such elevated activity correlates with a high oxidative metabolism and therefore the brain is dependent on antioxidants for protection against pathological conditions $[5,16]$. Redox imbalance and oxidative stress are observed during aging [17-19] and in neurodegenerative disorders such as Alzheimer's disease (AD), Parkinson's disease (PD), Huntington's disease (HD), Amyotrophic lateral sclerosis (ALS), among others [5,20-24]. 
Imbalance of ascorbic acid homeostasis has also been demonstrated in neurodegenerative disorders $[22,23,25,26]$. During the neurodegeneration process a clear link exists between ascorbic acid deficiency and oxidative-induced neuronal death. Therefore, emphasis should be placed on novel target discovery to prevent or fight oxidative stress, especially when designing molecules to ensure the correct supply of antioxidants, such as ascorbic acid, and developing new strategies to alleviate neurodegeneration progression $[27,28]$.

In this review, we will summarize the ascorbic acid functions in the Central Nervous System (CNS), mechanisms for ascorbic acid uptake and recycling, the relationship between redox imbalance and oxidative stress, and ascorbic acid homeostasis failure observed in several neurodegenerative disorders.

\section{General Aspects of Ascorbic Acid}

Ascorbic acid is involved in the first line of antioxidant defence, protecting lipid membranes and proteins from oxidative damage [6,29]. Ascorbic acid is synthesized in the liver of most mammals through the formation of D-glucuronic acid and L-gulono- $\gamma$-lactone. Humans, other primates, and guinea pigs do not express the functional enzyme L-gulono- $\gamma$-lactone oxidase and are therefore unable to synthesize ascorbic acid [30,31]. Thus, humans require a constant supply of ascorbic acid from fruit and vegetables. In this regard, mechanisms for ascorbic acid transport and recycling are important for ensuring distribution of this molecule in the brain $[1,32,33]$. The optimal dose of ascorbic acid to fully saturate plasma and tissues in healthy adults is $500 \mathrm{mg}$ [34]. Which far exceeds the recommended dosis $(60 \mathrm{mg})$ to prevent deficiency diseases [35] and promote general health [36]. At doses greater than $500 \mathrm{mg}$ urinary excretion of ascorbic acid is increased without changes of plasma levels [37,38].

\subsection{Ascorbic Acid Uptake and Distribution in the CNS}

Specific transporter systems actively driven by the sodium gradient are responsible for ascorbic acid uptake. Members of the transporter family SLC23, the Sodium dependent Vitamin C transporters 1 and 2 (SVCT1 and SVCT2), are expressed in multiple cell types [39-41]. In regards to vitamin C transporter expression in brain, SVCT2 is exclusively expressed in neurons $[39,41,42]$ hypothalamic glial cells [43] and epithelial cells from the choroid plexus [41]. The apical SVCT1 transporter participates in intestinal absorption, in the lumen of intestinal epithelium, and renal reabsorption of ascorbic acid [44,45]. Once ascorbic acid enters the bloodstream it is distributed to different organs. In the CNS, it is not fully understood how ascorbic acid is transported through the bloodcerebrospinal fluid (CSF) barrier [13] and blood-brain barrier (BBB) in endothelial cells of brain blood vessels [46] (Lam and Daniel, 1986). SVCT2 is expressed in the basolateral membrane of choroid plexus epithelia [47] therefore ascorbic acid is taken up from the blood into the intracellular space of epithelial cells. However, it is still unknown how ascorbic acid is released from choroid plexus cells to the CSF. SVCT2 expression at the BBB is not clear [48]. The entry of ascorbic acid to the brain via the BBB has been proposed to involve the SLC2A family of hexose transporters (GLUT) which are able to translocate dehydroascorbic acid; the oxidized form of vitamin C. It should be considered that under physiological conditions vitamin $C$ is present in the body mainly in the reduced form, ascorbic acid [6,49]. Thus, local oxidation of ascorbic acid to dehydroascorbic acid, uptake of the oxidised form by endothelial cells through GLUTs and intracellular reduction back to ascorbic acid should be necessary [8,50-53].

The brain exhibits one of the highest ascorbic acid concentrations in the body, with decreases of less than $2 \%$ per day [54]. Studies using mice have shown that the brain preferentially retains ascorbic acid at the expense of other tissues [5]. In whole brain, 1 to $2 \mathrm{mM}$ of ascorbic acid has been detected while intracellular neuronal concentrations are much higher, reaching up to $10 \mathrm{mM}[54,55]$. Cortex, nucleus accumbens, hypothalamus, hippocampus, choroid plexus and cerebrospinal fluid exhibit high concentrations of ascorbic acid $[13,31,56]$. In rat brain, ascorbic acid is present in CSF 
at a concentration of $500 \mu \mathrm{M}$ [57]. Since ascorbic acid is found in cerebral extracellular space at a concentration of $200-400 \mu \mathrm{M}[49,57,58]$, while blood levels are around $60 \mu \mathrm{M}$ [13], it highlights evidence of an active role of ascorbic acid uptake in the brain. Hence, regulation of ascorbic acid uptake and recycling are vital for its homeostasis.

\subsubsection{Ascorbic Acid Homeostasis and Synaptic Activity}

In mammalian tissues, CNS neurons are of particular interest because they contain high ascorbic acid concentrations, as mentioned above. Ascorbic acid is accumulated in neurons as a result of SVCT2 expression, the specific transporter for ascorbic acid [39,41,42]. Neurons are sensitive to ascorbic acid deficiency since they have an oxidative metabolism rate 10 -fold higher than glial cells $[16,59]$. It has been suggested that ascorbic acid has a neuroprotective role due to the existence of homeostatic mechanisms which maintain high concentrations of ascorbic acid in CSF and neurons $[4,5,16]$.

Ascorbic acid concentration in the brain changes according to neuronal activity. Thus, in response to brain activity, extracellular ascorbic acid concentrations are increased [60-63]. Accordingly, ascorbic acid efflux induced by synaptic activity from glial intracellular reservoirs can sustain the antioxidant requirements of active neurons and their high oxidative metabolism. A mechanism for neuronal ascorbic acid uptake-modulation was described by Acuña and colleagues, where an increase in extracellular ascorbic acid concentration (that occurs during synaptic activity) increases cell surface expression of the SVCT2 transporter, thus increasing ascorbic acid uptake [26].

Ascorbic acid is a potent reductant. When it carries out its antioxidant activity it is oxidized [64]. However, the reduction of its oxidised form is not a spontaneous event. It is an enzymatic reaction, which may be a glutathione-dependent $[7-9,65,66]$ or -independent [67-69] reaction (Figure 1). The mechanisms for ascorbic acid efflux and recycling carried out by astrocytes will be mentioned below.

\subsubsection{Mechanisms for Astrocytic Ascorbic Acid Recycling and Efflux}

Neurons exhibit high rates of oxidative metabolism. Oxidative processes generate free radicals which are scavenged by ascorbic acid. Neuronal cells express dehydroascorbic reductase which could be involved in ascorbic acid regeneration from its oxidized form; however, this enzyme is only expressed in pyramidal and Purkinje neurons. Hence, astrocytes take up and recycle ascorbic acid from the extracellular space participating in a coupling mechanism between astrocytes and neurons, where oxidative processes are mainly compartmentalized in neurons leading to the oxidation of ascorbic acid to dehydroascorbic acid. Facilitative glucose transporters (GLUTs) are responsible for dehydroascorbic acid uptake by CNS cells [4,70-72]. Neurons can release dehydroascorbic acid through GLUT3 or GLUT1 and then it is taken up by astrocytes where transport is restricted to a single isoform, GLUT1 (Figure 1). Moreover, studies show that primary cultures of astrocytes exclusively take up dehydroascorbic acid via a $\mathrm{Na}^{+}$-independent manner and are unable to transport ascorbic acid.

Glutathione (GSH, c-L-glutamyl-L-cysteinylglycine), vitamin E, and ascorbic acid are highly concentrated in astrocytes. They also express ROS-detoxifying enzymes such as GSH S-transferase, GSH peroxidase, and catalase [16,73-75]. Therefore astrocytes are resistant to oxidative damage [76,77]. After an oxidative insult, astrocytes undergo several processes which include expression of antioxidant enzymes $[77,78]$ and glucose oxidation through the pentose phosphate pathway, producing reducing agents for antioxidant regeneration [79-82] such as GSH synthesis for ascorbic acid recycling $[77,78]$. Oxidized ascorbic acid is thus reduced in the glial intracellular milieu and accumulated within astrocytes (Figure 1, [83]) and then the ascorbic acid could be released to the extracellular space in response to synaptic activity where it contributes to neuronal antioxidant defence $[26,61,62,84]$. 


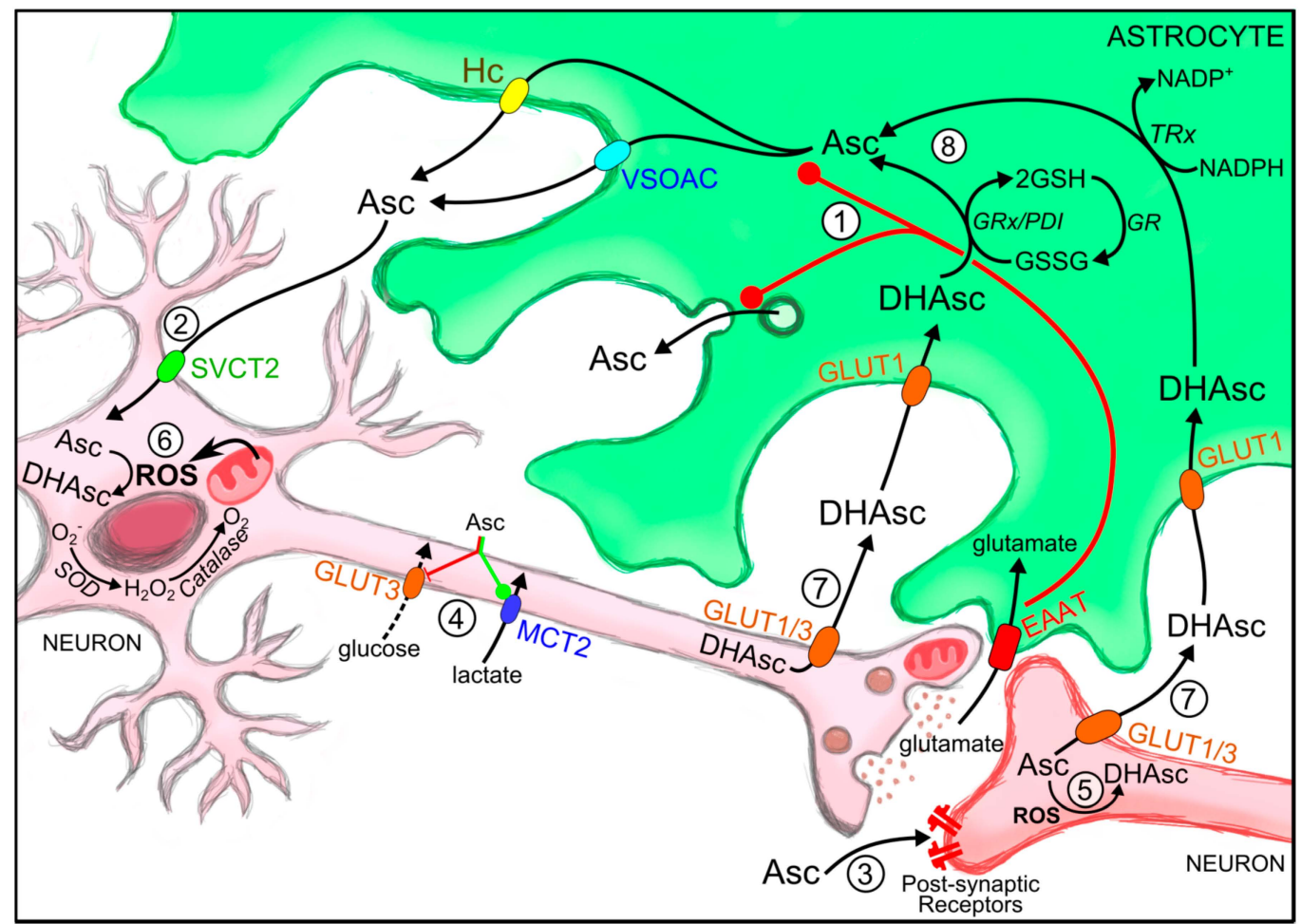

Figure 1. Roles of ascorbic acid during synaptic activity and astrocyte-mediated recycling. (1) During synaptic activity glutamate released into the synaptic space is taken up by astrocytes, where it stimulates ascorbic acid release from these cells through different hypothesized mechanisms (after astrocyte swelling by VSOAC induced via GLAST glutamate-aspartate transporter; Connexin-hemichannels; or through exocytosis of secretion vesicles); (2) Astrocyte-released ascorbic acid is taken up by neurons through SVCT2; (3) It participates as a neuromodulator (glutamatergic and GABA-ergic neurotransmission); (4) Regulates neuronal metabolic substrate preference via specific GLUT3 inhibition (metabolic switch). Reactive oxidant species (ROS) produced during synaptic activity (5) and neuronal metabolism (6) oxidize ascorbic acid to DHAsc; (7) DHAsc is released from neurons and is taken up by astrocytes through glucose transporters (GLUTs); (8) Astrocytes can reduce oxidized ascorbic acid via direct reaction with glutathione o via glutathione-dependent reductases such as glutaredoxin and protein disulfide isomerase. AMPAR, (2-amino-3-(3-hydroxy-5-methyl-isoxazol-4-yl) propanoic acid receptor; Asc, ascorbic acid; DHA, dehydroascorbic acid, oxidized ascorbic acid; EAAT, excitatory amino acid transporter; GABA ( $\gamma$ amino butyric acid); GLAST, (glutamate transporter in astrocytes); GLUT3, glucose transporter isoform 3; GSH, reduced gluthatione; GSSG, oxidized gluthatione; MCT, monocarboxylate transporter; ROS, reactive oxygen species; SVCT2, sodium-vitamin C transporter isoform 2; VSOAC, Volume-sensitive organic osmolyte-anion channel.

Since dehydroascorbic acid is a toxic molecule for the brain [85], astrocytes must rapidly reduce it in order to prevent dehydroascorbic acid retrotransport back to the extracellular space. Several pathways have been proposed for dehydroascorbic acid recycling in glial cells. Enzymatic reduction of dehydroascorbic acid has been described where GSH acts as a cofactor [86,87]. This could be conducted by GSH-dependent enzymes such as glutaredoxin, protein disulfide isomerase [88-90], and GSH S-transferase $\omega[65,91,92]$. Other mechanisms of intracellular dehydroascorbic acid reduction implicate NADPH-dependent reductases such as $3 \alpha$-hydroxysteroid dehydrogenase [93] and thioredoxin reductase [94-96]. Since astrocytes express four times more GSH than neurons they exhibit a higher capacity to reduce ascorbic acid [54]. Indeed, incubation with $0.2 \mathrm{mM}$ dehydroascorbic acid can decrease the intracellular concentration of GSH in cultured astrocytes [97]. 
Astrocytes are more efficient at scavenging ROS than neurons. Defence mechanisms against oxidative stress are essential for neuronal viability [16,73,98-100]. Astrocytes attenuate neuronal death caused by hydrogen peroxide when they are co-cultured with striatal neurons [74]. Several studies have shown that cultured neurons in the presence of astrocytes are more resistant to pro-oxidant agents such as hydrogen peroxide [101,102], nitric oxide [98,103], superoxide anion combined with nitric oxide, [104] or iron $[98,104]$. This glial neuroprotection has been detected at an astrocyte-neuron ratio of 1:20 [16].

A correlation exists between brain activity and extracellular ascorbic acid concentration [60-62,84]. Since astrocytes accumulate ascorbic acid they are suitable candidates for supplying this antioxidant in response to synaptic activity. In fact, neurotransmitter-stimulated release of ascorbic acid has been observed in cultured astrocytes (Figure 1, [105]). For example, glutamate released during synaptic activity, is cleared from the synaptic cleft by astrocytes through the glutamate transporter GLT1, to prevent excitotoxicity-induced neuronal death $[106,107]$. Furthermore, ascorbic acid seems to antagonize the negative effects of glutamate [31,108-110]. Glutamate-induced cellular swelling has been proposed as a mechanism for astrocytic ascorbic acid release [61,84,111,112], in fact, this release is observed through cell swelling alone [113]. Ascorbic acid release induced by hypotonic conditions was impeded by anion-transport inhibitors (4,4'-diisothiocyanostilbene-2, $2^{\prime}$-disulfonic acid; DIDS and 4,4'-dinitrostildene-2,2'-disulfonic acid; DNDS) suggesting anion-regulated release of ascorbic acid mediated by VSOAC (volume-sensitive organic osmolyte-anion channel, $[97,113,114])$. This should be considered in cases of ischemia where ion transport mechanisms regulating cell volume are reduced and could thus induce astrocyte swelling [115]. Ascorbic acid may also be released from astrocytes via other mechanisms. Studies have suggested ascorbic acid release through connexin hemichannels using Conexin 26 and 32 loaded liposomes [116-118]. Finally, ascorbic acid release through secretory vesicles has been described in parathyroid glands and adrenomedular vesicles after adrenergic and nicotinic stimulation [119].

\section{Roles of Ascorbic Acid at the CNS}

The main role of intracellular ascorbic acid in the CNS is to provide antioxidant protection against oxidative damage [68]. However it also functions as an enzymatic co-factor, participating in collagen [120-123], carnitine [124], tyrosine and peptidic hormone biosynthesis [125,126]. Severe dietary deficiency of ascorbic acid can cause health disorders such as scurvy syndrome [127-129]. Ascorbic acid deficiency has a negative impact on brain function particularly during development [130]. A high growth rate in a developing brain is responsible for an increased cellular metabolism. This together with an immature antioxidant system promotes redox imbalance [131]. Thus, levels of ascorbic acid in brain must be increased during early life [132]. Ascorbic acid deficiency during guinea pig pregnancy leads to persistent impairment of postnatal hippocampal development supporting the idea that maternal ascorbic acid deficiency exhibits severe consequences for the offspring [133]. In fact, the absence of ascorbic acid in the brain has been shown to be detrimental to newborn SVCT2 $(-/-)$ mice survival $[5,134]$.

Ascorbic acid is considered an important neuroprotective agent $[124,135,136]$ since it is a potent reducing agent, scavenging ROS production and sustaining superoxide dismutase and catalase activities [137]. It also protects neurons against glutamate excitotoxicity, which is associated with neurodegenerative processes [138-141]. However, ascorbic acid functions in the brain are broader than those based on its antioxidant properties (Figure 1).

\subsection{Ascorbic Acid as a Neuromodulator of Synaptic Activity}

Ascorbic acid affects synaptic neurotransmission by preventing neurotransmitter binding to receptors [142-144], by modulating their release and reuptake [145], and also acting as a cofactor in neurotransmitter synthesis $[146,147]$. Therefore, ascorbic acid is considered a nerudomodulator of neural transmission [5]. It could modulate synaptic receptors by reducing aminoacidic 
residues $[19,148]$ or by scavenging reactive oxygen species generated through neurotransmitter receptor activation [143,144]. Also, ascorbic acid participates in the conversion of dopamine to norepinephrine $[5,54]$ and it is essential for norephinephrine and acetylcholine release from synaptic vesicles [149]. Studies show that ascorbic acid modulates the activity of glutamate receptors, voltage-activated ionic channels, such as the neuronal T-type calcium channel $\left(\mathrm{Ca}^{+2}\right.$ (v) $3.2 \mathrm{~T}$-channel) and the voltage-dependent $\mathrm{K}^{+}$currents [144,150,151], and GABA receptors [152]. On the other hand, myelin formation in Schwann cells could be stimulated by ascorbic acid [153].

\subsection{Ascorbic Acid and the Ascorbic Acid Metabolic Switch}

Ascorbic acid can modulate neuronal metabolism switching the energy substrate preference from glucose to lactate during synaptic activity. The neuron-glia metabolic coupling model has gained force over the past decade, especially when tripartite synapse was described as a functional and structural unit, comprised of pre and post-synaptic terminals and glial processes surrounding the synaptic cleft [154].

The uptake of glutamate is able to stimulate glucose uptake, glycolysis and lactate release in astrocytes $[155,156]$. The astrocyte-neuron lactate shuttle (ANLS) hypothesis describes a functional mechanism of synaptic activity where lactate release from astrocytes is stimulated by glutamate uptake, and is then taken up by neurons to support their energetic needs. Neurons can take up released lactate through the monocarboxylate transporter 2 MCT2 $[157,158]$. This lactate flux is possible due to differential expression of monocarboxylate transporters and lactate dehydrogenase isoenzymes in neuronal and astroglial cells [159-162]. However, lactate transport and utilization by neurons is strongly debated since neurons are suitable for using glucose as their metabolic substrate [163-170]. In this context, the ascorbic acid metabolic switch proposes a mechanism responsible for the inhibition of neuronal glucose utilization during synaptic activity.

During the ascorbic acid metabolic switch, ascorbic acid released from glial cells is taken up by neurons where it inhibits glucose transport and utilization. This allows lactate uptake and metabolization as the primary energy source in neurons [10,11]. We have demonstrated neuronal inhibition of glucose usage by intracellular ascorbic acid through a mechanism involving GLUT3 [171]. Evidence of ascorbic acid recycling in the brain supported that idea [83] and it is independent of the antioxidant properties of ascorbic acid [172]. At the same time, intracellular ascorbic acid is capable of stimulating lactate uptake in neurons in a GLUT3-dependent manner [11].

\section{High Metabolism and ROS Production by Neurons}

\subsection{High Neuronal Metabolism during Synaptic Activity}

The brain is in charge of processing and regulating several physiological functions of the body, explaining its elevated energetic demands. In fact, even at rest the CNS accounts for up to $25 \%$ of oxygen consumption in adults $[14,173]$. Most of the energy utilized can be attributed to neuron and synapse related processes. Restoration of the membrane gradient after depolarization is the main energy demand of neurons. However, neurotransmitter recycling, dendritic and axonal transport, and intracellular signaling also account for a significant part of energy consumption [14]. Given that over $80 \%$ of neurons are excitatory and over $90 \%$ of synapses release glutamate, the major player in neuroenergetics is glutamatergic activity [174-176].

The CNS relies on glucose metabolism to sustain the energetic cost of synaptic activity. This molecule is a good source of potential energy, making it an efficient metabolic fuel and whose metabolism correlates with brain function $[60-62,84,177,178]$. There is a continuous glucose flow across the BBB through the glucose transporter GLUT1 [50,179-181], which is then taken up by neurons through GLUT3 and astrocytes through GLUT1. Glycolytic activity breaks down glucose to pyruvate in all brain cells, where the enzymes hexokinase, phosphofructokinase 1 , and to a lesser extent pyruvate kinase are the key control sites [182,183]. Lactate dehydrogenase is responsible 
for the conversion of pyruvate to lactate in glial cells and according to the previously mentioned ANLS hypothesis lactate is released to the extracellular space and taken up by neurons $[155,158,184]$. While glycolysis has a net yield of 2 ATP molecules, if glucose is subsequently oxidized through the tricarboxylic acid (TCA) cycle and oxidative phosphorylation, the production of ATP is increased to yield 30 to 36 molecules $[185,186]$. Thus, the high metabolism is a result of a significant demand for energy substrate utilization and elevated use of oxygen.

\subsection{ROS Production and the Ascorbic Acid Metabolic Switch}

TCA and oxidative phosphorylation form an efficient mechanism for sustaining synaptic activity. The neuronal glycolytic end-product pyruvate, astrocyte derived lactate, or blood-borne ketonic bodies are great sources to fuel mitochondrial processes [187-189]. Neurons change from the use of glucose to lactate through the ascorbic acid metabolic switch, allowing them to bypass glycolysis and oxidize lactate directly in the mitochondria $[10,11]$. However, the constant use of oxygen by the brain is responsible for the oxidative stress caused by the production of reactive oxygen species [190]. Not only metabolism but also synaptic signaling is a source of oxidative species. High glutamatergic activity causes an increase in extracellular glutamate, activating glutamate receptors (ionotropic NMDA, AMPA, and kainic acid receptors) which produce an elevated uptake of calcium promoting the production of reactive oxygen species [191-195]. Since neurons are highly sensitive to oxidative damage, mechanisms to maintain antioxidant activity are required during physiological activities such as recycling and release of ascorbic acid by astrocytes. However an imbalance in these processes leads to pathological conditions as discussed below.

\section{Oxidative Stress and Neurodegenerative Disorders}

While neurodegenerative diseases present a variety of symptoms and mechanisms which lead to the pathological state, most of them have in common a mitochondrial dysfunction, accumulation of abnormal proteins and production of ROS causing neuronal death. Moreover, increased ROS levels have been observed in post-mortem brain tissue from patients with neurodegenerative disorders, including Amyotrophic lateral sclerosis (ALS), Alzheimer's disease (AD), Huntington's disease (HD) and Parkinson's disease (PD). Overall, the brain tissue is vulnerable to oxidative damage caused by its high oxygen consumption metabolic rate.

\subsection{Redox Imbalance, Ascorbic Acid and Neurodegeneration}

The origin of oxidative stress in neurodegenerative disorders could be related with a redox imbalance, correlating with a deficiency of antioxidant defence enzymes, ascorbic acid supply and an altered ascorbic acid homeostasis in the CNS. Failure to supply or maintain ascorbic acid could affect the oxidative status of the cell. As we mentioned, several neurodegenerative diseases show increased levels of oxidative stress and thus treatment with antioxidant agents, in particular ascorbic acid, has been proposed to be beneficial for patients.

Here, we show several evidences supporting the involvement of ascorbic acid homeostasis in neurodegenerative diseases (Figure 2).

\subsubsection{Amyotrophic Lateral Sclerosis}

Amyotrophic lateral sclerosis (ALS) is a chronic neurodegenerative disorder [196]. Damage to motor neurons in the primary motor cortex, corticospinal tracts, brain stem, and spinal cord has been observed, leading to muscle weakness that typifies ALS. The causes of neurodegeneration in ALS are still unknown, but several researches suggest a role for mitochondrial dysfunction, excitotoxicity, cytoskeletal abnormalities, oxidative stress and protein aggregation [197]. Approximately 10\% of ALS are familial cases, and $20 \%$ are caused by mutations in the superoxide dismutase type 1 (SOD1) gene [198]. Mice expressing mutated SOD1 show calcium impairment, impaired electron transport chain activity and altered ROS production $[199,200]$. 
Oxidative stress has been proposed as a key player in the progression of neurodegeneration in ALS. One study suggests systemic oxidative stress in ALS patients, but without significate differences of ascorbic acid plasma levels and CSF levels. Another study showed lower ascorbic acid levels in the CSF from ALS patients in parallel with high levels of ascorbyl radicals, an oxidative stress marker. In ALS transgenic mice, treatment with a high dose of ascorbic acid before onset of the disease shows a beneficial effect, but this does not occur when administered after onset of the disease.

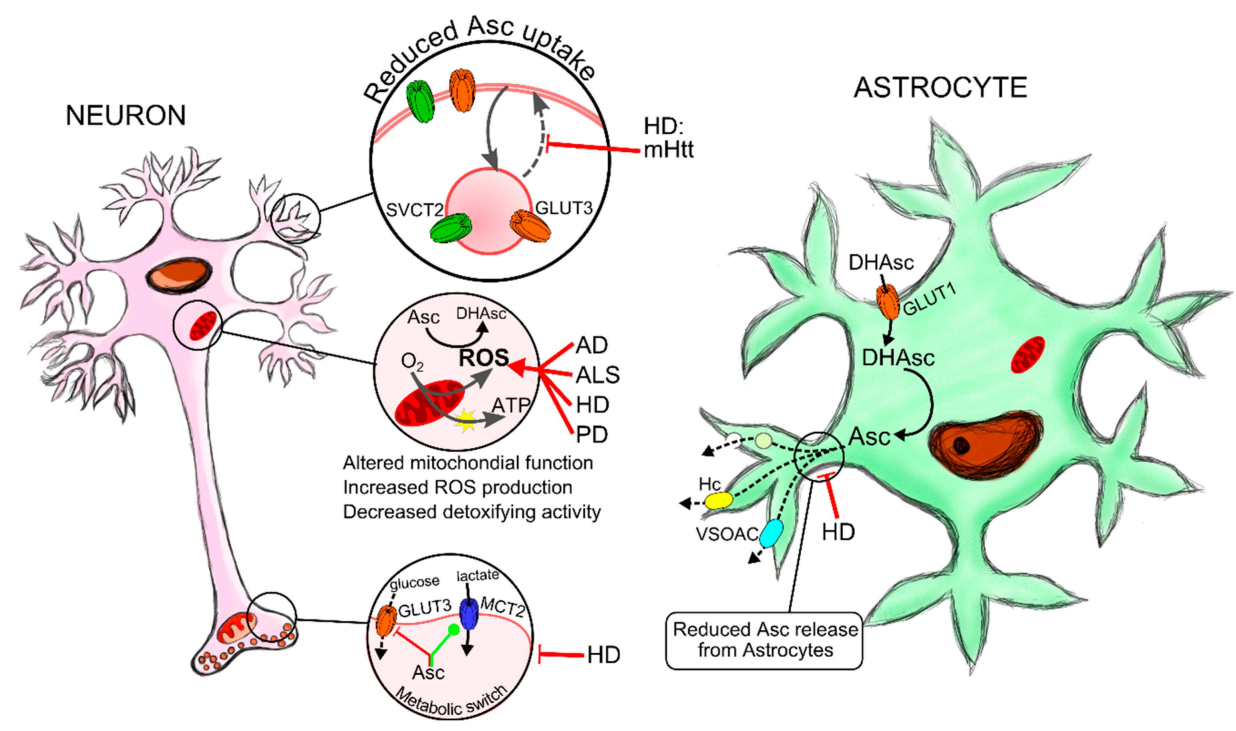

Figure 2. Failure in ascorbic acid homeostasis contributes to neurodegeneration. Neuronal TCA (tricarboxylic acid) and oxidative phosphorylation are highly efficient mechanisms in sustaining synaptic activity. However, the continued use of oxygen generates reactive oxygen species (ROS), which leads to oxidative stress. Therefore, neuronal metabolism and synaptic signalling induce ROS production. Neurons are highly sensitive to oxidative stress and thus ascorbic acid recycling by astrocytes and neuronal uptake through SVCT2 transporters are important mechanisms in maintaining antioxidant defence. During aging as well as in neurodegenerative diseases there is an imbalance in ROS production, decreased levels of antioxidant molecules and impairment in detoxifying enzyme activity such as superoxide dismutase (SOD) or catalase. In HD, accumulation of mutant Huntingtin protein alters mitochondrial biogenesis and expression of antioxidant defence genes, increasing oxidative damage leading to neuronal death. Amyloid $\beta$ peptide and $\alpha$-synuclein accumulation in $\mathrm{AD}$ and PD respectively, induce ROS production which in turn participates in protein aggregation and neuronal death in both pathologies. SOD1 loss of function due to its mutation is responsible for elevated ROS and causal for a type of ALS. Ascorbic acid levels tend to be reduced in AD, ALS, HD and PD. In HD, we have demonstrated that the failure in astrocytic ascorbic acid release and a decreased neuronal uptake, due to the reduced trafficking of SVCT2 and GLUT3 transporters to the cell surface, are responsible for the impaired metabolic switch, the decreased neuronal antioxidant protection and most likely HD metabolic failure and neuronal death. AD-Alzheimer's Disease; ALS-Amyotrophic lateral sclerosis; Huntington's disease-HD; Parkinson's Disease-PD; mHtt-mutant huntingtin; mSOD-mutant superoxide dismutase; SOD-Superoxide dismutase; ROS-reactive oxygen species.

\subsubsection{Alzheimer's Disease}

Alzheimer's Disease (AD) is a highly prevalent neurodegenerative disorder. It is characterized by progressive memory loss and cognitive dysfunction. Patients exhibit neuronal loss at the temporal lobe, parietal lobe, frontal cortex and cingulate gyrus, as well as other subcortical regions [201,202]. A neuropathological change that correlates with AD is the presence of neurofibrillary tangles (aggregates of hyperphosphorylated tau protein) accumulated in the neuronal 
cytosol and extracellular senile plaques, composed of $\beta$-amyloid $(A \beta)$ deposits which are derived from the amyloid precursor protein (APP) [203,204]. Evidence shows that mitochondrial impairment may induce formation of $A \beta$ plaques and neurofibrillary tangles [205-207]. Many studies indicate that $A \beta$ increases neuron vulnerability to oxidative stress and impairs the electron transport chain [206]. Oxidative stress induces amyloidogenic APP processing and increases $\beta$-secretase activity resulting in an accumulation of $A \beta$ peptide $[208,209]$. $A \beta$ oligomers interfere with mitochondrial dynamics [210,211]. Several studies demonstrate that $A \beta$ aggregation promotes ROS production [212]. Impairment in synaptic plasticity mediated by $A \beta$ peptide has also been demonstrated [213].

In recent studies, acute parenteral and intravenous treatment with ascorbic acid reversed some of the spatial learning and memory deficits found in AD transgenic mice without changing plaque deposition [214-216]. To examine the precise effect of ascorbic acid Kook and colleagues generated a transgenic mouse (5XFAD). These mice have depositions of amyloid plaques in the brain and are unable to synthesize ascorbic acid in vivo. They found that treatment with ascorbic acid reduced amyloid plaques, resulting in reduced blood brain barrier disruption and prevention of abnormal mitochondrial morphology. These results suggest that ascorbic acid could provide a protective effect against AD-like pathologies [217]. Ascorbic acid levels in plasma are decreased in AD patients $[218,219]$ and it has been suggested that increased dietary intake may reduce the risk of developing AD [220].

\subsubsection{Huntington's Disease}

Huntington's disease (HD) is a genetic disorder characterized by general neurodegeneration in brain with marked deterioration of medium-sized spiny neurons (MSNs) in the striatum [221]. The disease is caused by a mutation in the gene coding for huntingtin (Htt). Htt is an integrator of intracellular trafficking, favouring transport of vesicles, organelles and proteins to the cell surface [222,223]. Clinical symptoms of HD include a progressive increase in involuntary movements called chorea [224,225], cognitive deterioration [226], dementia and weight loss [227]. Enhanced oxidative damage in HD induces strand breaks in DNA in HD brain [228]. Also, in HD an increase of unsaturated fatty acid peroxidation [229] increased oxidation of proteins and lipids [230], as well an impaired SOD activity $[27,231,232]$ are observed. Defects on brain energy metabolism have been described in presymptomatic and symptomatic subjects [27,233-236], explained by decreased glucose metabolism, impaired mitochondrial ATP production, calcium homeostasis, trafficking and biogenesis [205,236-242]. On the other hand, post-mortem analyses in patients shows deficits in the activity of mitochondrial complexes I, II and III [24,238,241,243,244]. 3-Nitropropionic acid (3NP), an inhibitor of the mitochondrial complex II, has been reported to induce selective striatal damage [245]. In cells expressing mutant $\mathrm{Htt}$, 3-NP can induce mitochondrial dysfunction and cell death more easily [246]. Htt aggregates near mitochondria have been observed, suggesting $\mathrm{N}$-terminal interaction with the outer mitochondrial membrane [247-249]. Mutant Htt interaction with PGC-1 $\alpha$ decreases this factors ability to induce mitochondrial biogenesis [250,251]. PGC-1 $\alpha$ impaired function results in increased oxidative damage and neuronal death due down regulation of SOD and GSH peroxidase genes [252].

Impaired ascorbic acid homeostasis is observed in Huntington's disease animal models [109]. Analysis in animal models expressing mHtt show a decrease in extracellular ascorbic acid levels in the striatum after recovery from anaesthesia [253,254]. Only wild-type mice show an increase in extracellular ascorbic acid after anaesthesia, in contrast, R6/2 mice show the opposite response. A similar response was observed when striatal ascorbic acid release was evoked by cortical stimulation [254]. The loss of extracellular ascorbic acid also impacts striatal neuronal activity [255]. Acuña and colleagues (2013) demonstrated abnormal ascorbic acid release from astrocytes and impaired ascorbic acid uptake in neurons. This should explain alterations in neuronal metabolic substrate preferences in HD. Moreover, in experiments using immortalized striatal neurons 
expressing mutant huntingtin (STHdhQ cells), the ascorbic acid transporter 2 (SVCT2) fails to translocate to the plasma membrane when extracellular ascorbic acid concentration increases, leading to an impairment of ascorbic acid uptake in HD neurons. We have recently demonstrated that modulation of neuronal metabolism by ascorbic acid is independent of antioxidant properties of this molecule [172]. Thus increased ROS levels observed in HD (and other neurodegenerative diseases) should contribute to metabolic failure through the oxidation of ascorbic acid.

\subsubsection{Parkinson's Disease}

Parkinson's disease (PD) is a common neurodegenerative movement disorder. It is characterized by progressive degeneration of dopaminergic neurons in the substantia nigra pars compacta [256,257], the loss of innervation to the striatum and the subsequent release of dopamine [258-260]. Dementia, depression and behavioural deficiencies are also common in the advanced stages of the disease. PD is characterized by Lewy bodies inclusions which correspond to accumulations of $\alpha$-synuclein in neurons. Mutations in several genes are found in PD, including genes coding for $\alpha$-synuclein, leucine-rich repeat kinase 2 (LRRK2), DJ-1, PINK1 and ATP13A2 [261].

There are several evidences that mitochondrial dysfunction contributes to the pathogenesis of PD [262]. In fact, mitochondrial dysfunction has been related to mutations in PINK1 and DJ1 genes. Dopamine metabolism produces oxidant species therefore oxidative stress also occurs in PD [263-266]. On the other hand, oxidative stress participates in protein aggregation in PD. Modifications of the $\alpha$-synuclein by oxidative stress, including 4-hydroxy-2-nonenal, nitration and oxidation, have been implicated in oligomerization of $\alpha$-synuclein. These modifications are more likely to form oligomers compared to unmodified $\alpha$-synuclein [267].

Treatment of PD flies, exhibiting human- $\alpha$-synuclein in their neurons, with ascorbic acid demonstrated its protective effect as it delayed the loss of climbing ability [268]. Ascorbic acid may prevent cell death of dopaminergic human neurons in vitro; this may be due to the inhibition of oxidative stress [269]. Studies of ascorbic acid plasma levels from PD patients compared to controls are contradictory $[270,271]$. In one study, lymphocyte ascorbic acid levels were lower in PD patients. In the same patient cohort, plasma ascorbic acid levels also tended to be lower. Lymphocyte ascorbic acid levels could act as a potential biomarker for progression of PD [272].

\section{Conclusions}

In summary, ascorbic acid stands out in the defence against oxidative stress in the CNS. Its antioxidant activity is of vital importance, given the elevated ROS production by the high metabolic rate implicated in the specialized and complex functions needed to sustain neurotransmission.

Taking into consideration the different roles of ascorbic acid here described, as an antioxidant molecule, a neuromodulator of synaptic activity and its function on the metabolic switch in neurons during brain activity and resting conditions, this molecule appears as a key factor in physiological and pathological conditions.

Ascorbic acid has been tested as a neuroprotective agent in patients for the treatment of neurodegenerative diseases such as PD and ALS [273]. In the case of HD, favourable data has only been recapitulated from in vitro studies $[26,143]$ and pre-clincal tests using mice [253]. While in vitro analyzes show very promising results, in vivo assays show modest improvements of the symptomatology. One of the major problems in the use of ascorbic acid in neuroprotective therapy is associated with the low stability of this molecule. Ascorbic acid is rapidly oxidized in solutions and when in contact with the air.

Neurodegenerative diseases which exhibit high oxidative stress constantly consume ascorbic acid available in the brain [172]. When ascorbic acid is used as an antioxidant, it is oxidized. Therefore in the presence of high levels of ROS no ascorbic acid remains available to modulate neuronal metabolism. Thus oxidative stress, elevated ROS production and the failure of homeostatic systems for ascorbic acid recycling are crucial aspects in the progression of neurodegeneration. Therefore, it is 
important to continue the efforts to thoroughly evaluate the roles of ascorbic acid for the development of new therapies against neurodegenerative disorders.

Acknowledgments: We would like to acknowledge the helpful suggestions and discussion of Jaione Arteaga and Raúl Alava. This work was supported by Chilean FONDECYT grant 1151206 (MAC), Chilean CONICYT grants 21110592 (ACP) and 21100320 (FAB), DID-UACh University Research Grant from the Universidad Austral de Chile, Valdivia, Chile (MAC) and International SfA grant (MAC). ACP, AIA, FAB and LT are CONICYT fellows.

Author Contributions: The work presented here was carried out in collaboration between all authors. Maite Aintzane Castro, Adriana Covarrubias-Pinto and Aníbal Ignacio Acuña designed the project. Adriana Covarrubias-Pinto, Aníbal Ignacio Acuña, Felipe Andrés Beltrán and Leandro Torres-Díaz wrote the manuscript. Aníbal Ignacio Acuña prepared the figures. Maite Aintzane Castro revised the entire manuscript.

Conflicts of Interest: The authors declare no conflict of interest.

\section{Abbreviations}

A $\beta$ : $\beta$-amyloid peptide; AD: Alzheimer's disease; ALS: Amyotrophic lateral sclerosis; AMPAR: $\alpha$-amino-3-hydroxy-5-methyl-4-isoxazolepropionic acid receptor; ANLS: astrocyte-neuron lactate shuttle; ATP: adenosine triphosphat; APP: amyloid precursor protein; BBB: blood-brain barrier; $\mathrm{Ca}^{+2}$ (v) 3.2 T-channel: neuronal t-type calcium channel; CSF: cerebrospinal fluid barrier; CNS: Central Nervous System; GABA: $\gamma$ amino butyric acid; GLT1: astrocytic glutamate transporter; GLAST: astrocytic glutamate transporter; GLUTs: glucose transporters; GSH: glutathione, c-L-glutamyl-L-cysteinylglycine; HD: Huntington's disease; HTT: huntingtin protein; OH8dG: 8-hydroxy-2'-deoxyguanosine; LRRK2: leucine-rich repeat kinase 2; LTP: long-term potentiation process; MCTs: monocarboxylate transporter; MSSNs: medium-sized spiny neurons; NADPH: Nicotinamide adenine dinucleotide phosphate; 3NP: 3-Nitropropionic acid; NMDAR: $N$-methyl-D-aspartate receptor; PD: Parkinson's disease; PGC- $1 \alpha$ : proliferator-activated receptor $\gamma$ co-activator $1 \alpha$; ROS: reactive oxygen species; SLC2: family of glucose transporters; SLC23: family of ascorbate transporters; SOD1: superoxide dismutase 1; SVCTs: Sodium dependent vitamin C transporter; TCA: tricarboxylic acid; VSOAC: volume-sensitive organic osmolyte-anion channel.

\section{References}

1. Du, J.; Cullen, J.J.; Buettner, G.R. Ascorbic acid: Chemistry, biology and the treatment of cancer. Biochim. Biophys. Acta 2012, 1826, 443-457. [CrossRef] [PubMed]

2. Lachapelle, M.Y.; Drouin, G. Inactivation dates of the human and guinea pig vitamin C genes. Genetica 2011, 139, 199-207. [CrossRef] [PubMed]

3. Nishikimi, M.; Kawai, T.; Yagi, K. Guinea pigs possess a highly mutated gene for L-gulono- $\gamma$-lactone oxidase, the key enzyme for L-ascorbic acid biosynthesis missing in this species. J. Biol. Chem. 1992, 267, 21967-21972. [PubMed]

4. May, J.M. Vitamin c transport and its role in the central nervous system. Subcell. Biochem. 2012, 56, 85-103. [PubMed]

5. Harrison, F.E.; May, J.M. Vitamin c function in the brain: Vital role of the ascorbate transporter SVCT2. Free Radic. Biol. Med. 2009, 46, 719-730. [CrossRef] [PubMed]

6. Frei, B.; England, L.; Ames, B.N. Ascorbate is an outstanding antioxidant in human blood plasma. Proc. Natl. Acad. Sci. USA 1989, 86, 6377-6381. [CrossRef] [PubMed]

7. Park, J.B.; Levine, M. Purification, cloning and expression of dehydroascorbic acid-reducing activity from human neutrophils: Identification as glutaredoxin. Biochem. J. 1996, 315, 931-938. [CrossRef] [PubMed]

8. Himmelreich, U.; Drew, K.N.; Serianni, A.S.; Kuchel, P.W. 13C NMR studies of vitamin C transport and its redox cycling in human erythrocytes. Biochemistry 1998, 37, 7578-7588. [CrossRef] [PubMed]

9. Ishikawa, T.; Casini, A.F.; Nishikimi, M. Molecular cloning and functional expression of rat liver glutathione-dependent dehydroascorbate reductase. J. Biol. Chem. 1998, 273, 28708-28712. [CrossRef] [PubMed] 
10. Castro, M.A.; Pozo, M.; Cortes, C.; Garcia Mde, L.; Concha, I.I.; Nualart, F. Intracellular ascorbic acid inhibits transport of glucose by neurons, but not by astrocytes. J. Neurochem. 2007, 102, 773-782. [CrossRef] [PubMed]

11. Castro, M.A.; Angulo, C.; Brauchi, S.; Nualart, F.; Concha, I.I. Ascorbic acid participates in a general mechanism for concerted glucose transport inhibition and lactate transport stimulation. Pflugers Arch. 2008, 457, 519-528. [CrossRef] [PubMed]

12. Castro, M.A.; Beltrán, F.A.; Brauchi, S.; Concha, I.I. A metabolic switch in brain: Glucose and lactate metabolism modulation by ascorbic acid. J. Neurochem. 2009, 110, 423-440. [CrossRef] [PubMed]

13. Spector, R.; Lorenzo, A.V. Ascorbic acid homeostasis in the central nervous system. Am. J. Physiol. 1973, 225, 757-763. [PubMed]

14. Attwell, D.; Laughlin, S.B. An energy budget for signaling in the grey matter of the brain. J. Cereb. Blood Flow Metab. 2001, 21, 1133-1145. [CrossRef] [PubMed]

15. Alle, H.; Roth, A.; Geiger, J.R. Energy-efficient action potentials in hippocampal mossy fibers. Science 2009, 325, 1405-1408. [CrossRef] [PubMed]

16. Wilson, J.X. Antioxidant defense of the brain: A role for astrocytes. Can. J. Physiol. Pharmacol. 1997, 75, 1149-1163. [CrossRef] [PubMed]

17. Rodriguez, K.A.; Wywial, E.; Perez, V.I.; Lambert, A.J.; Edrey, Y.H.; Lewis, K.N.; Grimes, K.; Lindsey, M.L.; Brand, M.D.; Buffenstein, R. Walking the oxidative stress tightrope: A perspective from the naked mole-rat, the longest-living rodent. Curr. Pharm. Des. 2011, 17, 2290-2307. [CrossRef] [PubMed]

18. Sahoo, A.; Chainy, G.B. Alterations in the activities of cerebral antioxidant enzymes of rat are related to aging. Int. J. Dev. Neurosci. 1997, 15, 939-948. [CrossRef]

19. Ciani, E.; Groneng, L.; Voltattorni, M.; Rolseth, V.; Contestabile, A.; Paulsen, R.E. Inhibition of free radical production or free radical scavenging protects from the excitotoxic cell death mediated by glutamate in cultures of cerebellar granule neurons. Brain Res. 1996, 728, 1-6. [CrossRef]

20. Heafield, M.T.; Fearn, S.; Steventon, G.B.; Waring, R.H.; Williams, A.C.; Sturman, S.G. Plasma cysteine and sulphate levels in patients with motor neurone, parkinson's and alzheimer's disease. Neurosci. Lett. 1990, 110, 216-220. [CrossRef]

21. Halliwell, B. Oxidative stress and neurodegeneration: Where are we now? J. Neurochem. 2006, 97, $1634-1658$. [CrossRef] [PubMed]

22. Goswami, A.; Dikshit, P.; Mishra, A.; Mulherkar, S.; Nukina, N.; Jana, N.R. Oxidative stress promotes mutant huntingtin aggregation and mutant huntingtin-dependent cell death by mimicking proteasomal malfunction. Biochem. Biophys. Res. Commun. 2006, 342, 184-190. [CrossRef] [PubMed]

23. Wyttenbach, A.; Sauvageot, O.; Carmichael, J.; Diaz-Latoud, C.; Arrigo, A.P.; Rubinsztein, D.C. Heat shock protein 27 prevents cellular polyglutamine toxicity and suppresses the increase of reactive oxygen species caused by huntingtin. Hum. Mol. Genet. 2002, 11, 1137-1151. [CrossRef] [PubMed]

24. Browne, S.E.; Bowling, A.C.; MacGarvey, U.; Baik, M.J.; Berger, S.C.; Muqit, M.M.; Bird, E.D.; Beal, M.F. Oxidative damage and metabolic dysfunction in huntington's disease: Selective vulnerability of the basal ganglia. Ann. Neurol. 1997, 41, 646-653. [CrossRef] [PubMed]

25. Warner, T.A.; Kang, J.Q.; Kennard, J.A.; Harrison, F.E. Low brain ascorbic acid increases susceptibility to seizures in mouse models of decreased brain ascorbic acid transport and alzheimer's disease. Epilepsy Res. 2015, 110, 20-25. [CrossRef] [PubMed]

26. Acuña, A.I.; Esparza, M.; Kramm, C.; Beltrán, F.A.; Parra, A.V.; Cepeda, C.; Toro, C.A.; Vidal, R.L.; Hetz, C.; Concha, I.I.; et al. A failure in energy metabolism and antioxidant uptake precede symptoms of huntington's disease in mice. Nat. Commun. 2013, 4, 2917. [CrossRef] [PubMed]

27. Mazziotta, J.C.; Phelps, M.E.; Pahl, J.J.; Huang, S.C.; Baxter, L.R.; Riege, W.H.; Hoffman, J.M.; Kuhl, D.E.; Lanto, A.B.; Wapenski, J.A.; et al. Reduced cerebral glucose metabolism in asymptomatic subjects at risk for huntington's disease. N. Engl. J. Med. 1987, 316, 357-362. [CrossRef] [PubMed]

28. Navarro, A.; Boveris, A. Brain mitochondrial dysfunction and oxidative damage in parkinson's disease. J. Bioenerg. Biomembr. 2009, 41, 517-521. [CrossRef] [PubMed]

29. Berger, T.M.; Polidori, M.C.; Dabbagh, A.; Evans, P.J.; Halliwell, B.; Morrow, J.D.; Roberts, L.J., 2nd; Frei, B. Antioxidant activity of vitamin C in iron-overloaded human plasma. J. Biol. Chem. 1997, 272, 15656-15660. [CrossRef] [PubMed] 
30. Kiuchi, K.; Nishikimi, M.; Yagi, K. Purification and characterization of L-gulonolactone oxidase from chicken kidney microsomes. Biochemistry 1982, 21, 5076-5082. [CrossRef] [PubMed]

31. Grunewald, R.A. Ascorbic acid in the brain. Brain Res. Brain Res. Rev. 1993, 18, 123-133. [CrossRef]

32. Harrison, F.E.; Bowman, G.L.; Polidori, M.C. Ascorbic acid and the brain: Rationale for the use against cognitive decline. Nutrients 2014, 6, 1752-1781. [CrossRef] [PubMed]

33. Siliprandi, L.; Vanni, P.; Kessler, M.; Semenza, G. Na+-dependent, electroneutral L-ascorbate transport across brush border membrane vesicles from guinea pig small intestine. BBA Biomembr. 1979, 552, 129-142. [CrossRef]

34. Levine, M.; Wang, Y.; Padayatty, S.J.; Morrow, J. A new recommended dietary allowance of vitamin C for healthy young women. Proc. Nat. Acad. Sci. USA 2001, 98, 9842-9846. [CrossRef] [PubMed]

35. Carr, A.C.; Frei, B. Toward a new recommended dietary allowance for vitamin $\mathrm{C}$ based on antioxidant and health effects in humans. Am. J. Clin. Nutr. 1999, 69, 1086-1107. [PubMed]

36. Deruelle, F.; Baron, B. Vitamin C: Is supplementation necessary for optimal health? J. Altern. Complement. Med. 2008, 14, 1291-1298. [CrossRef] [PubMed]

37. Levine, G.N.; Frei, B.; Koulouris, S.N.; Gerhard, M.D.; Keaney, J.F., Jr.; Vita, J.A. Ascorbic acid reverses endothelial vasomotor dysfunction in patients with coronary artery disease. Circulation 1996, 93, 1107-1113. [CrossRef] [PubMed]

38. Friedman, G.J.; Sherry, S.; Ralli, E.P. The mechanism of the excretion of vitamin c by the human kidney at low and normal plasma levels of ascorbic acid. J. Clin. Investig. 1940, 19, 685-689. [CrossRef] [PubMed]

39. Faaland, C.A.; Race, J.E.; Ricken, G.; Warner, F.J.; Williams, W.J.; Holtzman, E.J. Molecular characterization of two novel transporters from human and mouse kidney and from LLC-PK1 cells reveals a novel conserved family that is homologous to bacterial and aspergillus nucleobase transporters. BBA Gene Struct. Expr. 1998, 1442, 353-360. [CrossRef]

40. Daruwala, R.; Song, J.; Koh, W.S.; Rumsey, S.C.; Levine, M. Cloning and functional characterization of the human sodium-dependent vitamin C transporters HSVCT1 and HSVCT2. FEBS Lett. 1999, 460, 480-484. [CrossRef]

41. Tsukaguchi, H.; Tokui, T.; Mackenzie, B.; Berger, U.V.; Chen, X.Z.; Wang, Y.; Brubaker, R.F.; Hediger, M.A. A family of mammalian Na+-dependent L-ascorbic acid transporters. Nature 1999, 399, 70-75. [PubMed]

42. Castro, M.; Caprile, T.; Astuya, A.; Millan, C.; Reinicke, K.; Vera, J.C.; Vasquez, O.; Aguayo, L.G.; Nualart, F. High-affinity sodium-vitamin C co-transporters (SVCT) expression in embryonic mouse neurons. J. Neurochem. 2001, 78, 815-823. [CrossRef] [PubMed]

43. Garcia Mde, L.; Salazar, K.; Millan, C.; Rodriguez, F.; Montecinos, H.; Caprile, T.; Silva, C.; Cortes, C.; Reinicke, K.; Vera, J.C.; et al. Sodium vitamin C cotransporter SVCT2 is expressed in hypothalamic glial cells. Glia 2005, 50, 32-47. [CrossRef] [PubMed]

44. Takanaga, H.; Mackenzie, B.; Hediger, M.A. Sodium-dependent ascorbic acid transporter family SLC23. Pflugers Arch. 2004, 447, 677-682. [CrossRef] [PubMed]

45. Wilson, J.X. Regulation of vitamin C transport. Annu. Rev. Nutr. 2005, 25, 105-125. [CrossRef] [PubMed]

46. Lam, D.K.; Daniel, P.M. The influx of ascorbic acid into the rat's brain. Quart. J. Exp. Physiol. 1986, 71, 483-489. [CrossRef]

47. Angelow, S.; Haselbach, M.; Galla, H.J. Functional characterisation of the active ascorbic acid transport into cerebrospinal fluid using primary cultured choroid plexus cells. Brain Res. 2003, 988, 105-113. [CrossRef]

48. Nualart, F.; Mack, L.; Garcia, A.; Cisternas, P.; Bongarzone, E.R.; Heitzer, M.; Jara, N.; Martinez, F.; Ferrada, L.; Espinoza, F.; et al. Vitamin C transporters, recycling and the bystander effect in the nervous system: SVCT2 versus gluts. J. Stem Cell Res. Ther. 2014, 4, 209. [CrossRef] [PubMed]

49. Schenk, J.O.; Miller, E.; Gaddis, R.; Adams, R.N. Homeostatic control of ascorbate concentration in CNS extracellular fluid. Brain Res. 1982, 253, 353-356. [CrossRef]

50. Agus, D.B.; Gambhir, S.S.; Pardridge, W.M.; Spielholz, C.; Baselga, J.; Vera, J.C.; Golde, D.W. Vitamin C crosses the blood-brain barrier in the oxidized form through the glucose transporters. J. Clin. Investig. 1997, 100, 2842-2848. [CrossRef] [PubMed]

51. Taverna, R.D.; Langdon, R.G. Reversible association of cytochalasin B with the human erythrocyte membrane. Inhibition of glucose transport and the stoichiometry of cytochalasin binding. BBA Biomembr. 1973, 323, 207-219. [CrossRef] 
52. Agus, D.B.; Vera, J.C.; Golde, D.W. Stromal cell oxidation: A mechanism by which tumors obtain vitamin C. Cancer Res. 1999, 59, 4555-4558. [PubMed]

53. Nualart, F.J.; Rivas, C.I.; Montecinos, V.P.; Godoy, A.S.; Guaiquil, V.H.; Golde, D.W.; Vera, J.C. Recycling of vitamin C by a bystander effect. J. Biol. Chem. 2003, 278, 10128-10133. [CrossRef] [PubMed]

54. Rice, M.E. Ascorbate regulation and its neuroprotective role in the brain. Trends Neurosci. 2000, 23, $209-216$. [CrossRef]

55. Rice, M.E.; Russo-Menna, I. Differential compartmentalization of brain ascorbate and glutathione between neurons and glia. Neuroscience 1998, 82, 1213-1223. [CrossRef]

56. Milby, K.; Oke, A.; Adams, R.N. Detailed mapping of ascorbate distribution in rat brain. Neurosci. Lett. 1982, 28, 169-174. [CrossRef]

57. Stamford, J.A.; Kruk, Z.L.; Millar, J. Regional differences in extracellular ascorbic acid levels in the rat brain determined by high speed cyclic voltammetry. Brain Res. 1984, 299, 289-295. [CrossRef]

58. Miele, M.; Fillenz, M. In vivo determination of extracellular brain ascorbate. J. Neurosci. Methods 1996, 70, 15-19. [CrossRef]

59. Hediger, M.A. New view at C. Nat. Med. 2002, 8, 445-446. [CrossRef] [PubMed]

60. Basse-Tomusk, A.; Rebec, G.V. Regional distribution of ascorbate and 3,4-dihydroxyphenylacetic acid (DOPAC) in rat striatum. Brain Res. 1991, 538, 29-35. [CrossRef]

61. Ghasemzadeh, B.; Cammack, J.; Adams, R.N. Dynamic changes in extracellular fluid ascorbic acid monitored by in vivo electrochemistry. Brain Res. 1991, 547, 162-166. [CrossRef]

62. O'Neill, R.D.; Fillenz, M.; Sundstrom, L.; Rawlins, J.N. Voltammetrically monitored brain ascorbate as an index of excitatory amino acid release in the unrestrained rat. Neurosci. Lett. 1984, 52, 227-233. [CrossRef]

63. Boutelle, M.G.; Svensson, L.; Fillenz, M. Rapid changes in striatal ascorbate in response to tail-pinch monitored by constant potential voltammetry. Neuroscience 1989, 30, 11-17. [CrossRef]

64. Carr, A.; Frei, B. Does vitamin C act as a pro-oxidant under physiological conditions? FASEB J. 1999, 13, 1007-1024. [PubMed]

65. Maellaro, E.; del Bello, B.; Sugherini, L.; Santucci, A.; Comporti, M.; Casini, A.F. Purification and characterization of glutathione-dependent dehydroascorbate reductase from rat liver. Biochem. J. 1994, 301, 471-476. [CrossRef] [PubMed]

66. Washburn, M.P.; Wells, W.W. Identification of the dehydroascorbic acid reductase and thioltransferase (glutaredoxin) activities of bovine erythrocyte glutathione peroxidase. Biochem. Biophys. Res. Commun. 1999, 257, 567-571. [CrossRef] [PubMed]

67. Guaiquil, V.H.; Farber, C.M.; Golde, D.W.; Vera, J.C. Efficient transport and accumulation of vitamin C in Hl-60 cells depleted of glutathione. J. Biol. Chem. 1997, 272, 9915-9921. [PubMed]

68. May, J.M.; Qu, Z.C.; Mendiratta, S. Protection and recycling of $\alpha$-tocopherol in human erythrocytes by intracellular ascorbic acid. Arch. Biochem. Biophys. 1998, 349, 281-289. [CrossRef] [PubMed]

69. Savini, I.; Duflot, S.; Avigliano, L. Dehydroascorbic acid uptake in a human keratinocyte cell line (HaCaT) is glutathione-independent. Biochem. J. 2000, 345(3), 665-672. [CrossRef] [PubMed]

70. Nualart, F.; Salazar, K.; Oyarce, K.; Cisternas, P.; Jara, N.; Silva-Alvarez, C.; Pastor, P.; Martinez, F.; Garcia, A.; Garcia-Robles Mde, L.; et al. Typical and atypical stem cells in the brain, vitamin C effect and neuropathology. Biol. Res. 2012, 45, 243-256. [CrossRef] [PubMed]

71. Rumsey, S.C.; Kwon, O.; Xu, G.W.; Burant, C.F.; Simpson, I.; Levine, M. Glucose transporter isoforms GLUT1 and GLUT3 transport dehydroascorbic acid. J. Biol. Chem. 1997, 272, 18982-18989. [CrossRef] [PubMed]

72. Vera, J.C.; Rivas, C.I.; Fischbarg, J.; Golde, D.W. Mammalian facilitative hexose transporters mediate the transport of dehydroascorbic acid. Nature 1993, 364, 79-82. [CrossRef] [PubMed]

73. Makar, T.K.; Nedergaard, M.; Preuss, A.; Gelbard, A.S.; Perumal, A.S.; Cooper, A.J. Vitamin E, ascorbate, glutathione, glutathione disulfide, and enzymes of glutathione metabolism in cultures of chick astrocytes and neurons: Evidence that astrocytes play an important role in antioxidative processes in the brain. J. Neurochem. 1994, 62, 45-53. [CrossRef] [PubMed]

74. Desagher, S.; Glowinski, J.; Premont, J. Astrocytes protect neurons from hydrogen peroxide toxicity. J. Neurosci. 1996, 16, 2553-2562. [PubMed] 
75. Dringen, R.; Kussmaul, L.; Gutterer, J.M.; Hirrlinger, J.; Hamprecht, B. The glutathione system of peroxide detoxification is less efficient in neurons than in astroglial cells. J. Neurochem. 1999, 72, 2523-2530. [CrossRef] [PubMed]

76. Rohl, C.; Armbrust, E.; Herbst, E.; Jess, A.; Gulden, M.; Maser, E.; Rimbach, G.; Bosch-Saadatmandi, C. Mechanisms involved in the modulation of astroglial resistance to oxidative stress induced by activated microglia: Antioxidative systems, peroxide elimination, radical generation, lipid peroxidation. Neurotox. Res. 2010, 17, 317-331. [CrossRef] [PubMed]

77. Macco, R.; Pelizzoni, I.; Consonni, A.; Vitali, I.; Giacalone, G.; Martinelli Boneschi, F.; Codazzi, F.; Grohovaz, F.; Zacchetti, D. Astrocytes acquire resistance to iron-dependent oxidative stress upon proinflammatory activation. J. Neuroinflamm. 2013, 10, 130. [CrossRef] [PubMed]

78. Almeida, A.; Almeida, J.; Bolanos, J.P.; Moncada, S. Different responses of astrocytes and neurons to nitric oxide: The role of glycolytically generated ATP in astrocyte protection. Proc. Natl. Acad. Sci. USA 2001, 98, 15294-15299. [CrossRef] [PubMed]

79. Garcia-Nogales, P.; Almeida, A.; Bolanos, J.P. Peroxynitrite protects neurons against nitric oxide-mediated apoptosis. A key role for glucose-6-phosphate dehydrogenase activity in neuroprotection. J. Biol. Chem. 2003, 278, 864-874. [CrossRef] [PubMed]

80. Ben-Yoseph, O.; Boxer, P.A.; Ross, B.D. Assessment of the role of the glutathione and pentose phosphate pathways in the protection of primary cerebrocortical cultures from oxidative stress. J. Neurochem. 1996, 66, 2329-2337. [CrossRef] [PubMed]

81. Lovatt, D.; Sonnewald, U.; Waagepetersen, H.S.; Schousboe, A.; He, W.; Lin, J.H.; Han, X.; Takano, T.; Wang, S.; Sim, F.J.; et al. The transcriptome and metabolic gene signature of protoplasmic astrocytes in the adult murine cortex. J. Neurosci. 2007, 27, 12255-12266. [CrossRef] [PubMed]

82. Cahoy, J.D.; Emery, B.; Kaushal, A.; Foo, L.C.; Zamanian, J.L.; Christopherson, K.S.; Xing, Y.; Lubischer, J.L.; Krieg, P.A.; Krupenko, S.A.; et al. A transcriptome database for astrocytes, neurons, and oligodendrocytes: A new resource for understanding brain development and function. J. Neurosci. 2008, 28, 264-278. [CrossRef] [PubMed]

83. Astuya, A.; Caprile, T.; Castro, M.; Salazar, K.; Garcia Mde, L.; Reinicke, K.; Rodriguez, F.; Vera, J.C.; Millan, C.; Ulloa, V.; et al. Vitamin C uptake and recycling among normal and tumor cells from the central nervous system. J. Neurosci. Res. 2005, 79, 146-156. [CrossRef] [PubMed]

84. Yusa, T. Increased extracellular ascorbate release reflects glutamate re-uptake during the early stage of reperfusion after forebrain ischemia in rats. Brain Res. 2001, 897, 104-113. [CrossRef]

85. Patterson, J.W.; Mastin, D.W. Some effects of dehydroascorbic acid on the central nervous system. Am. J. Physiol. 1951, 167, 119-126. [PubMed]

86. Deponte, M. Glutathione catalysis and the reaction mechanisms of glutathione-dependent enzymes. BBA Gen. Subj. 2013, 1830, 3217-3266. [CrossRef] [PubMed]

87. Winkler, B.S.; Orselli, S.M.; Rex, T.S. The redox couple between glutathione and ascorbic acid: A chemical and physiological perspective. Free Radic. Biol. Med. 1994, 17, 333-349. [CrossRef]

88. Wells, W.W.; Xu, D.P.; Yang, Y.F.; Rocque, P.A. Mammalian thioltransferase (glutaredoxin) and protein disulfide isomerase have dehydroascorbate reductase activity. J. Biol. Chem. 1990, 265, 15361-15364. [PubMed]

89. Wells, W.W.; Xu, D.P. Dehydroascorbate reduction. J. Bioenerg. Biomembr. 1994, 26, 369-377. [CrossRef] [PubMed]

90. Linster, C.L.; van Schaftingen, E. Vitamin C. Biosynthesis, recycling and degradation in mammals. FEBS J. 2007, 274, 1-22. [CrossRef] [PubMed]

91. Board, P.G.; Coggan, M.; Chelvanayagam, G.; Easteal, S.; Jermiin, L.S.; Schulte, G.K.; Danley, D.E.; Hoth, L.R.; Griffor, M.C.; Kamath, A.V.; et al. Identification, characterization, and crystal structure of the $\omega$ class glutathione transferases. J. Biol. Chem. 2000, 275, 24798-24806. [CrossRef] [PubMed]

92. Whitbread, A.K.; Masoumi, A.; Tetlow, N.; Schmuck, E.; Coggan, M.; Board, P.G. Characterization of the $\omega$ class of glutathione transferases. Methods Enzymol. 2005, 401, 78-99. [PubMed]

93. Del Bello, B.; Maellaro, E.; Sugherini, L.; Santucci, A.; Comporti, M.; Casini, A.F. Purification of NADPH-dependent dehydroascorbate reductase from rat liver and its identification with 3 $\alpha$-hydroxysteroid dehydrogenase. Biochem. J. 1994, 304, 385-390. [CrossRef] [PubMed] 
94. Mendiratta, S.; Qu, Z.C.; May, J.M. Enzyme-dependent ascorbate recycling in human erythrocytes: Role of thioredoxin reductase. Free Radic. Biol. Med. 1998, 25, 221-228. [CrossRef]

95. Rose, R.C. Cerebral metabolism of oxidized ascorbate. Brain Res. 1993, 628, 49-55. [CrossRef]

96. Dragan, M.; Dixon, S.J.; Jaworski, E.; Chan, T.S.; O’Brien, P.J.; Wilson, J.X. Coenzyme Q1 depletes NAD(P)H and impairs recycling of ascorbate in astrocytes. Brain Res. 2006, 1078, 9-18. [CrossRef] [PubMed]

97. Siushansian, R.; Tao, L.; Dixon, S.J.; Wilson, J.X. Cerebral astrocytes transport ascorbic acid and dehydroascorbic acid through distinct mechanisms regulated by cyclic AMP. J. Neurochem. 1997, 68, 2378-2385. [CrossRef] [PubMed]

98. Tanaka, J.; Toku, K.; Zhang, B.; Ishihara, K.; Sakanaka, M.; Maeda, N. Astrocytes prevent neuronal death induced by reactive oxygen and nitrogen species. Glia 1999, 28, 85-96. [CrossRef]

99. Gegg, M.E.; Beltran, B.; Salas-Pino, S.; Bolanos, J.P.; Clark, J.B.; Moncada, S.; Heales, S.J. Differential effect of nitric oxide on glutathione metabolism and mitochondrial function in astrocytes and neurones: Implications for neuroprotection/neurodegeneration? J. Neurochem. 2003, 86, 228-237. [CrossRef] [PubMed]

100. Dringen, R.; Pfeiffer, B.; Hamprecht, B. Synthesis of the antioxidant glutathione in neurons: Supply by astrocytes of CysGly as precursor for neuronal glutathione. J. Neurosci. 1999, 19, 562-569. [PubMed]

101. Langeveld, C.H.; Jongenelen, C.A.; Schepens, E.; Stoof, J.C.; Bast, A.; Drukarch, B. Cultured rat striatal and cortical astrocytes protect mesencephalic dopaminergic neurons against hydrogen peroxide toxicity independent of their effect on neuronal development. Neurosci. Lett. 1995, 192, 13-16. [CrossRef]

102. Fujita, T.; Tozaki-Saitoh, H.; Inoue, K. P2y1 receptor signaling enhances neuroprotection by astrocytes against oxidative stress via il-6 release in hippocampal cultures. Glia 2009, 57, 244-257. [CrossRef] [PubMed]

103. Chen, Y.; Vartiainen, N.E.; Ying, W.; Chan, P.H.; Koistinaho, J.; Swanson, R.A. Astrocytes protect neurons from nitric oxide toxicity by a glutathione-dependent mechanism. J. Neurochem. 2001, 77, 1601-1610. [CrossRef] [PubMed]

104. Lucius, R.; Sievers, J. Postnatal retinal ganglion cells in vitro: Protection against reactive oxygen species (ROS)-induced axonal degeneration by cocultured astrocytes. Brain Res. 1996, 743, 56-62. [CrossRef]

105. Wilson, J.X.; Peters, C.E.; Sitar, S.M.; Daoust, P.; Gelb, A.W. Glutamate stimulates ascorbate transport by astrocytes. Brain Res. 2000, 858, 61-66. [CrossRef]

106. Selkirk, J.V.; Nottebaum, L.M.; Vana, A.M.; Verge, G.M.; Mackay, K.B.; Stiefel, T.H.; Naeve, G.S.; Pomeroy, J.E.; Petroski, R.E.; Moyer, J.; et al. Role of the GLT-1 subtype of glutamate transporter in glutamate homeostasis: The GLT-1-preferring inhibitor way-855 produces marginal neurotoxicity in the rat hippocampus. Eur. J. Neurosci. 2005, 21, 3217-3228. [CrossRef] [PubMed]

107. Bak, L.K.; Schousboe, A.; Waagepetersen, H.S. The glutamate/gaba-glutamine cycle: Aspects of transport, neurotransmitter homeostasis and ammonia transfer. J. Neurochem. 2006, 98, 641-653. [CrossRef] [PubMed]

108. Miele, M.; Boutelle, M.G.; Fillenz, M. The physiologically induced release of ascorbate in rat brain is dependent on impulse traffic, calcium influx and glutamate uptake. Neuroscience 1994, 62, 87-91. [CrossRef]

109. Rebec, G.V.; Pierce, R.C. A vitamin as neuromodulator: Ascorbate release into the extracellular fluid of the brain regulates dopaminergic and glutamatergic transmission. Prog. Neurobiol. 1994, 43, 537-565. [CrossRef]

110. Bell, J.A.; Beglan, C.L.; London, E.D. Interaction of ascorbic acid with the neurotoxic effects of NMDA and sodium nitroprusside. Life Sci. 1996, 58, 367-371. [CrossRef]

111. Lane, D.J.; Lawen, A. The glutamate aspartate transporter (GLAST) mediates L-glutamate-stimulated ascorbate-release via swelling-activated anion channels in cultured neonatal rodent astrocytes. Cell Biochem. Biophys. 2013, 65, 107-119. [CrossRef] [PubMed]

112. Cammack, J.; Ghasemzadeh, B.; Adams, R.N. The pharmacological profile of glutamate-evoked ascorbic acid efflux measured by in vivo electrochemistry. Brain Res. 1991, 565, 17-22. [CrossRef]

113. Siushansian, R.; Dixon, S.J.; Wilson, J.X. Osmotic swelling stimulates ascorbate efflux from cerebral astrocytes. J. Neurochem. 1996, 66, 1227-1233. [CrossRef] [PubMed]

114. Corti, A.; Casini, A.F.; Pompella, A. Cellular pathways for transport and efflux of ascorbate and dehydroascorbate. Arch. Biochem. Biophys. 2010, 500, 107-115. [CrossRef] [PubMed]

115. Ekholm, A.; Katsura, K.; Kristian, T.; Liu, M.; Folbergrova, J.; Siesjo, B.K. Coupling of cellular energy state and ion homeostasis during recovery following brain ischemia. Brain Res. 1993, 604, 185-191. [CrossRef] 
116. Ahmad, S.; Evans, W.H. Post-translational integration and oligomerization of connexin 26 in plasma membranes and evidence of formation of membrane pores: Implications for the assembly of gap junctions. Biochem. J. 2002, 365, 693-699. [CrossRef] [PubMed]

117. Locke, D.; Koreen, I.V.; Liu, J.Y.; Harris, A.L. Reversible pore block of connexin channels by cyclodextrins. J. Biol. Chem. 2004, 279, 22883-22892. [CrossRef] [PubMed]

118. Ramundo-Orlando, A.; Serafino, A.; Schiavo, R.; Liberti, M.; d'Inzeo, G. Permeability changes of connexin32 hemi channels reconstituted in liposomes induced by extremely low frequency, low amplitude magnetic fields. BBA Biomembr. 2005, 1668, 33-40. [CrossRef] [PubMed]

119. Von Zastrow, M.; Tritton, T.R.; Castle, J.D. Identification of L-ascorbic acid in secretion granules of the rat parotid gland. J. Biol. Chem. 1984, 259, 11746-11750. [PubMed]

120. Kivirikko, K.I.; Prockop, D.J. Hydroxylation of proline in synthetic polypeptides with purified protocollagen hydroxylase. J. Biol. Chem. 1967, 242, 4007-4012. [PubMed]

121. Kivirikko, K.I.; Prockop, D.J. Enzymatic hydroxylation of proline and lysine in protocollagen. Proc. Nat. Acad. Sci. USA 1967, 57, 782-789. [CrossRef] [PubMed]

122. Kivirikko, K.I.; Prockop, D.J. Partial characterization of protocollagen from embryonic cartilage. Biochem. J. 1967, 102, 432-442. [CrossRef] [PubMed]

123. Peterkofsky, B. Ascorbate requirement for hydroxylation and secretion of procollagen: Relationship to inhibition of collagen synthesis in scurvy. Am. J. Clin. Nutr. 1991, 54, 1135S-1140S. [PubMed]

124. Padh, H. Cellular functions of ascorbic acid. Biochem. Cell Biol. 1990, 68, 1166-1173. [CrossRef] [PubMed]

125. Levine, M.; Wang, Y.; Rumsey, S.C. Analysis of ascorbic acid and dehydroascorbic acid in biological samples. Methods Enzymol. 1999, 299, 65-76. [PubMed]

126. Chatterjee, I.B.; Majumder, A.K.; Nandi, B.K.; Subramanian, N. Synthesis and some major functions of vitamin C in animals. Ann. N. Y. Acad. Sci. 1975, 258, 24-47. [CrossRef] [PubMed]

127. Padayatty, S.J.; Levine, M. Vitamin C and coronary microcirculation. Circulation 2001, 103, E117. [CrossRef] [PubMed]

128. Verrax, J.; Calderon, P.B. The controversial place of vitamin C in cancer treatment. Biochem. Pharmacol. 2008, 76, 1644-1652. [CrossRef] [PubMed]

129. Traber, M.G.; Stevens, J.F. Vitamins C and E: Beneficial effects from a mechanistic perspective. Free Radic. Biol. Med. 2011, 51, 1000-1013. [CrossRef] [PubMed]

130. Tveden-Nyborg, P.; Johansen, L.K.; Raida, Z.; Villumsen, C.K.; Larsen, J.O.; Lykkesfeldt, J. Vitamin C deficiency in early postnatal life impairs spatial memory and reduces the number of hippocampal neurons in guinea pigs. Am. J. Clin. Nutr. 2009, 90, 540-546. [CrossRef] [PubMed]

131. Lykkesfeldt, J.; Trueba, G.P.; Poulsen, H.E.; Christen, S. Vitamin C deficiency in weanling guinea pigs: Differential expression of oxidative stress and DNA repair in liver and brain. Br. J. Nutr. 2007, 98, 1116-1119. [CrossRef] [PubMed]

132. Kratzing, C.C.; Kelly, J.D.; Kratzing, J.E. Ascorbic acid in fetal rat brain. J. Neurochem. 1985, 44, $1623-1624$. [CrossRef] [PubMed]

133. Tveden-Nyborg, P.; Vogt, L.; Schjoldager, J.G.; Jeannet, N.; Hasselholt, S.; Paidi, M.D.; Christen, S.; Lykkesfeldt, J. Maternal vitamin C deficiency during pregnancy persistently impairs hippocampal neurogenesis in offspring of guinea pigs. PLOS ONE 2012, 7, e48488. [CrossRef] [PubMed]

134. Sotiriou, S.; Gispert, S.; Cheng, J.; Wang, Y.; Chen, A.; Hoogstraten-Miller, S.; Miller, G.F.; Kwon, O.; Levine, M.; Guttentag, S.H.; et al. Ascorbic-acid transporter Slc23a1 is essential for vitamin C transport into the brain and for perinatal survival. Nat. Med. 2002, 8, 514-517. [CrossRef] [PubMed]

135. Naseer, M.I.; Ullah, N.; Ullah, I.; Koh, P.O.; Lee, H.Y.; Park, M.S.; Kim, M.O. Vitamin C protects against ethanol and PTZ-induced apoptotic neurodegeneration in prenatal rat hippocampal neurons. Synapse 2011, 65, 562-571. [CrossRef] [PubMed]

136. Niki, E. Action of ascorbic acid as a scavenger of active and stable oxygen radicals. Am. J. Clin. Nutr. 1991, 54, 1119S-1124S. [PubMed]

137. Santos, I.M.; Tome Ada, R.; Saldanha, G.B.; Ferreira, P.M.; Militao, G.C.; Freitas, R.M. Oxidative stress in the hippocampus during experimental seizures can be ameliorated with the antioxidant ascorbic acid. Oxid. Med. Cell. Longev. 2009, 2, 214-221. [CrossRef] [PubMed] 
138. Qiu, S.; Li, L.; Weeber, E.J.; May, J.M. Ascorbate transport by primary cultured neurons and its role in neuronal function and protection against excitotoxicity. J. Neurosci. Res. 2007, 85, 1046-1056. [CrossRef] [PubMed]

139. Coyle, J.T.; Puttfarcken, P. Oxidative stress, glutamate, and neurodegenerative disorders. Science 1993, 262, 689-695. [CrossRef] [PubMed]

140. Lipton, S.A.; Rosenberg, P.A. Excitatory amino acids as a final common pathway for neurologic disorders. N. Engl. J. Med. 1994, 330, 613-622. [PubMed]

141. Choi, D.W. Glutamate neurotoxicity and diseases of the nervous system. Neuron 1988, 1, 623-634. [CrossRef]

142. Todd, R.D.; Bauer, P.A. Ascorbate modulates 5-[3H]hydroxytryptamine binding to central 5-HT3 sites in bovine frontal cortex. J. Neurochem. 1988, 50, 1505-1512. [CrossRef] [PubMed]

143. Majewska, M.D.; Bell, J.A. Ascorbic acid protects neurons from injury induced by glutamate and NMDA. Neuroreport 1990, 1, 194-196. [CrossRef] [PubMed]

144. Majewska, M.D.; Bell, J.A.; London, E.D. Regulation of the NMDA receptor by redox phenomena: Inhibitory role of ascorbate. Brain Res. 1990, 537, 328-332. [CrossRef]

145. Levine, M.; Morita, K.; Heldman, E.; Pollard, H.B. Ascorbic acid regulation of norepinephrine biosynthesis in isolated chromaffin granules from bovine adrenal medulla. J. Biol. Chem. 1985, 260, 15598-15603. [PubMed]

146. Levine, M.; Morita, K.; Pollard, H. Enhancement of norepinephrine biosynthesis by ascorbic acid in cultured bovine chromaffin cells. J. Biol. Chem. 1985, 260, 12942-12947. [PubMed]

147. Paterson, I.A.; Hertz, L. Sodium-independent transport of noradrenaline in mouse and rat astrocytes in primary culture. J. Neurosci. Res. 1989, 23, 71-77. [CrossRef] [PubMed]

148. Atlante, A.; Gagliardi, S.; Minervini, G.M.; Ciotti, M.T.; Marra, E.; Calissano, P. Glutamate neurotoxicity in rat cerebellar granule cells: A major role for xanthine oxidase in oxygen radical formation. J. Neurochem. 1997, 68, 2038-2045. [CrossRef] [PubMed]

149. Kuo, C.H.; Hata, F.; Yoshida, H.; Yamatodani, A.; Wada, H. Effect of ascorbic acid on release of acetylcholine from synaptic vesicles prepared from different species of animals and release of noradrenaline from synaptic vesicles of rat brain. Life Sci. 1979, 24, 911-915. [CrossRef]

150. Fan, S.F.; Yazulla, S. Modulation of voltage-dependent $k+$ currents $\left(I_{\mathrm{k}(\mathrm{v})}\right)$ in retinal bipolar cells by ascorbate is mediated by dopamine d1 receptors. Vis. Neurosci. 1999, 16, 923-931. [CrossRef] [PubMed]

151. Nelson, M.T.; Joksovic, P.M.; Su, P.; Kang, H.W.; Van Deusen, A.; Baumgart, J.P.; David, L.S.; Snutch, T.P.; Barrett, P.Q.; Lee, J.H.; et al. Molecular mechanisms of subtype-specific inhibition of neuronal $t$-type calcium channels by ascorbate. J. Neurosci. 2007, 27, 12577-12583. [CrossRef] [PubMed]

152. Calero, C.I.; Vickers, E.; Moraga Cid, G.; Aguayo, L.G.; von Gersdorff, H.; Calvo, D.J. Allosteric modulation of retinal GABA receptors by ascorbic acid. J. Neurosci. 2011, 31, 9672-9682. [CrossRef] [PubMed]

153. Eldridge, C.F.; Bunge, M.B.; Bunge, R.P.; Wood, P.M. Differentiation of axon-related schwann cells in vitro. I. Ascorbic acid regulates basal lamina assembly and myelin formation. J. Cell Biol. 1987, 105, 1023-1034. [CrossRef] [PubMed]

154. Araque, A.; Parpura, V.; Sanzgiri, R.P.; Haydon, P.G. Tripartite synapses: Glia, the unacknowledged partner. Trends Neurosci. 1999, 22, 208-215. [CrossRef]

155. Pellerin, L.; Magistretti, P.J. Glutamate uptake into astrocytes stimulates aerobic glycolysis: A mechanism coupling neuronal activity to glucose utilization. Proc. Natl. Acad. Sci. USA 1994, 91, 10625-10629. [CrossRef] [PubMed]

156. Demestre, M.; Boutelle, M.; Fillenz, M. Stimulated release of lactate in freely moving rats is dependent on the uptake of glutamate. J. Physiol. 1997, 499, 825-832. [CrossRef] [PubMed]

157. Magistretti, P.J.; Pellerin, L. The astrocyte-mediated coupling between synaptic activity and energy metabolism operates through volume transmission. Prog. Brain Res. 2000, 125, 229-240. [PubMed]

158. Allaman, I.; Gavillet, M.; Belanger, M.; Laroche, T.; Viertl, D.; Lashuel, H.A.; Magistretti, P.J. Amyloid- $\beta$ aggregates cause alterations of astrocytic metabolic phenotype: Impact on neuronal viability. J. Neurosci. 2010, 30, 3326-3338. [CrossRef] [PubMed]

159. Bittar, P.G.; Charnay, Y.; Pellerin, L.; Bouras, C.; Magistretti, P.J. Selective distribution of lactate dehydrogenase isoenzymes in neurons and astrocytes of human brain. J. Cereb. Blood Flow Metab. 1996, 16, 1079-1089. [CrossRef] [PubMed] 
160. Laughton, J.D.; Charnay, Y.; Belloir, B.; Pellerin, L.; Magistretti, P.J.; Bouras, C. Differential messenger RNA distribution of lactate dehydrogenase LDH-1 and LDH-5 isoforms in the rat brain. Neuroscience 2000, 96, 619-625. [CrossRef]

161. Pellerin, L.; Bergersen, L.H.; Halestrap, A.P.; Pierre, K. Cellular and subcellular distribution of monocarboxylate transporters in cultured brain cells and in the adult brain. J. Neurosci. Res. 2005, 79, 55-64. [CrossRef] [PubMed]

162. Pierre, K.; Pellerin, L. Monocarboxylate transporters in the central nervous system: Distribution, regulation and function. J. Neurochem. 2005, 94, 1-14. [CrossRef] [PubMed]

163. Chih, C.P.; Roberts, E.L., Jr. Energy substrates for neurons during neural activity: A critical review of the astrocyte-neuron lactate shuttle hypothesis. J. Cereb. Blood Flow Metab. 2003, 23, 1263-1281. [CrossRef] [PubMed]

164. Dienel, G.A.; Wang, R.Y.; Cruz, N.F. Generalized sensory stimulation of conscious rats increases labeling of oxidative pathways of glucose metabolism when the brain glucose-oxygen uptake ratio rises. J. Cereb. Blood Flow Metab. 2002, 22, 1490-1502. [CrossRef] [PubMed]

165. Gjedde, A. Cerebral blood flow change in arterial hypoxemia is consistent with negligible oxygen tension in brain mitochondria. Neuroimage 2002, 17, 1876-1881. [PubMed]

166. Hertz, L. The astrocyte-neuron lactate shuttle: A challenge of a challenge. J. Cereb. Blood Flow Metab. 2004, 24, 1241-1248. [CrossRef] [PubMed]

167. Hertz, L.; Kala, G. Energy metabolism in brain cells: Effects of elevated ammonia concentrations. Metab. Brain Dis. 2007, 22, 199-218. [CrossRef] [PubMed]

168. Mangia, S.; Garreffa, G.; Bianciardi, M.; Giove, F.; di Salle, F.; Maraviglia, B. The aerobic brain: Lactate decrease at the onset of neural activity. Neuroscience 2003, 118, 7-10. [CrossRef]

169. Mangia, S.; Giove, F.; Bianciardi, M.; di Salle, F.; Garreffa, G.; Maraviglia, B. Issues concerning the construction of a metabolic model for neuronal activation. J. Neurosci Res. 2003, 71, 463-467. [CrossRef] [PubMed]

170. Mangia, S.; Simpson, I.A.; Vannucci, S.J.; Carruthers, A. The in vivo neuron-to-astrocyte lactate shuttle in human brain: Evidence from modeling of measured lactate levels during visual stimulation. J. Neurochem. 2009, 109 (Suppl. 1), 55-62. [CrossRef] [PubMed]

171. Beltrán, F.A.; Acuña, A.I.; Miro, M.P.; Angulo, C.; Concha, I.I.; Castro, M.A. Ascorbic acid-dependent GLUT3 inhibition is a critical step for switching neuronal metabolism. J. Cell. Physiol. 2011, 226, 3286-3294. [CrossRef] [PubMed]

172. Covarrubias-Pinto, A.; Moll, P.; Solis-Maldonado, M.; Acuña, A.I.; Riveros, A.; Paz Miro, M.; Papic, E.; Beltrán, F.A.; Cepeda, C.; Concha, I.I.; et al. Beyond the redox imbalance: Oxidative stress contributes to an impaired GLUT3 modulation in huntington's disease. Free Radic. Biol. Med. 2015. [CrossRef] [PubMed]

173. Mink, J.W.; Blumenschine, R.J.; Adams, D.B. Ratio of central nervous system to body metabolism in vertebrates: Its constancy and functional basis. Am. J. Physiol. 1981, 241, R203-R212. [PubMed]

174. Abeles, M. Corticonics: Neural Circuits of the Cerebral Cortex; Cambridge University Press: New York, NY, USA, 1991; p. 280.

175. Braitenberg, V.; Schüz, A. Cortex: Statistics and Geometry of Neuronal Connectivity; Springer: Berlin, Germany, 1998.

176. Sibson, N.R.; Dhankhar, A.; Mason, G.F.; Rothman, D.L.; Behar, K.L.; Shulman, R.G. Stoichiometric coupling of brain glucose metabolism and glutamatergic neuronal activity. Proc. Natl. Acad. Sci. USA 1998, 95, 316-321. [CrossRef] [PubMed]

177. Sokoloff, L.; Reivich, M.; Kennedy, C.; Des Rosiers, M.H.; Patlak, C.S.; Pettigrew, K.D.; Sakurada, O.; Shinohara, M. The [14C]deoxyglucose method for the measurement of local cerebral glucose utilization: Theory, procedure, and normal values in the conscious and anesthetized albino rat. J. Neurochem. 1977, 28, 897-916. [CrossRef] [PubMed]

178. Giove, F.; Mangia, S.; Bianciardi, M.; Garreffa, G.; di Salle, F.; Morrone, R.; Maraviglia, B. The physiology and metabolism of neuronal activation: In vivo studies by NMR and other methods. Magn. Reson. Imaging 2003, 21, 1283-1293. [CrossRef] [PubMed]

179. Boado, R.J.; Pardridge, W.M. Measurement of blood-brain barrier glut1 glucose transporter and actin mRNA by a quantitative polymerase chain reaction assay. J. Neurochem. 1994, 62, 2085-2090. [CrossRef] [PubMed] 
180. Bolz, S.; Farrell, C.L.; Dietz, K.; Wolburg, H. Subcellular distribution of glucose transporter (GLUT-1) during development of the blood-brain barrier in rats. Cell Tissue Res. 1996, 284, 355-365. [CrossRef] [PubMed]

181. Nualart, F.; Godoy, A.; Reinicke, K. Expression of the hexose transporters GLUT1 and GLUT2 during the early development of the human brain. Brain Res. 1999, 824, 97-104. [CrossRef]

182. Maher, F.; Vannucci, S.; Takeda, J.; Simpson, I.A. Expression of mouse-GLUT3 and human-GLUT3 glucose transporter proteins in brain. Biochem. Biophys. Res. Commun. 1992, 182, 703-711. [CrossRef]

183. Lowry, O.H.; Passonneau, J.V. The relationships between substrates and enzymes of glycolysis in brain. J. Biol. Chem. 1964, 239, 31-42. [PubMed]

184. Beltrán, F.A.; Acuña, A.I.; Miró, M.P.; Castro, M. Brain energy metabolism in health and disease. In Neuroscience-Dealing with Frontiers; Contreras, C.M., Ed. InTech: Rijeka, Croatia, 2012; p. 32.

185. Kety, S.S. The general metabolism of the brain in vivo. In The Metabolism of the Nervous System; Richter, D., Ed.; Elsevier: Philadelphia, PA, USA, 1957; p. 17.

186. Sokoloff, L. Quantitative measurements of cerebral blood flow in man. Methods Med. Res. 1960, 8, $253-261$. [PubMed]

187. Schurr, A.; West, C.A.; Rigor, B.M. Lactate-supported synaptic function in the rat hippocampal slice preparation. Science 1988, 240, 1326-1328. [CrossRef] [PubMed]

188. Izumi, Y.; Ishii, K.; Katsuki, H.; Benz, A.M.; Zorumski, C.F. $\beta$-Hydroxybutyrate fuels synaptic function during development. Histological and physiological evidence in rat hippocampal slices. J. Clin. Investing. 1998, 101, 1121-1132. [CrossRef] [PubMed]

189. Wyss, M.T.; Jolivet, R.; Buck, A.; Magistretti, P.J.; Weber, B. In vivo evidence for lactate as a neuronal energy source. J. Neurosci. 2011, 31, 7477-7485. [CrossRef] [PubMed]

190. Chinopoulos, C.; Adam-Vizi, V. Mitochondria deficient in complex I activity are depolarized by hydrogen peroxide in nerve terminals: Relevance to parkinson's disease. J. Neurochem. 2001, 76, 302-306. [CrossRef] [PubMed]

191. Dawson, V.L.; Dawson, T.M.; London, E.D.; Bredt, D.S.; Snyder, S.H. Nitric oxide mediates glutamate neurotoxicity in primary cortical cultures. Proc. Natl. Acad. Sci. USA 1991, 88, 6368-6371. [CrossRef] [PubMed]

192. Lafon-Cazal, M.; Pietri, S.; Culcasi, M.; Bockaert, J. NMDA-dependent superoxide production and neurotoxicity. Nature 1993, 364, 535-537. [CrossRef] [PubMed]

193. Bondy, S.C.; Lee, D.K. Oxidative stress induced by glutamate receptor agonists. Brain Res. 1993, 610, 229-233. [CrossRef]

194. Vesce, S.; Kirk, L.; Nicholls, D.G. Relationships between superoxide levels and delayed calcium deregulation in cultured cerebellar granule cells exposed continuously to glutamate. J. Neurochem. 2004, 90, 683-693. [CrossRef] [PubMed]

195. Kahlert, S.; Zundorf, G.; Reiser, G. Glutamate-mediated influx of extracellular Ca2+ is coupled with reactive oxygen species generation in cultured hippocampal neurons but not in astrocytes. J. Neurosci. Res. 2005, 79, 262-271. [CrossRef] [PubMed]

196. Neymotin, A.; Petri, S.; Calingasan, N.Y.; Wille, E.; Schafer, P.; Stewart, C.; Hensley, K.; Beal, M.F.; Kiaei, M. Lenalidomide (revlimid) administration at symptom onset is neuroprotective in a mouse model of amyotrophic lateral sclerosis. Exp. Neurol. 2009, 220, 191-197. [CrossRef] [PubMed]

197. Shaw, P.J. Molecular and cellular pathways of neurodegeneration in motor neurone disease. J. Neurol. Neurosurg. Psychiatry 2005, 76, 1046-1057. [CrossRef] [PubMed]

198. Rosen, D.R.; Siddique, T.; Patterson, D.; Figlewicz, D.A.; Sapp, P.; Hentati, A.; Donaldson, D.; Goto, J.; O'Regan, J.P.; Deng, H.X.; et al. Mutations in $\mathrm{Cu} / \mathrm{Zn}$ superoxide dismutase gene are associated with familial amyotrophic lateral sclerosis. Nature 1993, 362, 59-62. [CrossRef] [PubMed]

199. Lin, M.T.; Beal, M.F. Mitochondrial dysfunction and oxidative stress in neurodegenerative diseases. Nature 2006, 443, 787-795. [CrossRef] [PubMed]

200. Mattiazzi, M.; D’Aurelio, M.; Gajewski, C.D.; Martushova, K.; Kiaei, M.; Beal, M.F.; Manfredi, G. Mutated human sod1 causes dysfunction of oxidative phosphorylation in mitochondria of transgenic mice. J. Biol. Chem. 2002, 277, 29626-29633. [CrossRef] [PubMed]

201. Orth, M.; Schapira, A.H. Mitochondria and degenerative disorders. Am. J. Med. Genet. 2001, 106, $27-36$. [CrossRef] [PubMed]

202. Wenk, G.L. Neuropathologic changes in alzheimer's disease. J. Clin. Psychiatry 2003, 64, 7-10. [PubMed] 
203. Duyckaerts, C.; Delatour, B.; Potier, M.C. Classification and basic pathology of alzheimer disease. Acta Neuropathol. 2009, 118, 5-36. [CrossRef] [PubMed]

204. Anandatheerthavarada, H.K.; Devi, L. Amyloid precursor protein and mitochondrial dysfunction in alzheimer's disease. Neuroscientist 2007, 13, 626-638. [CrossRef] [PubMed]

205. Gu, M.; Gash, M.T.; Mann, V.M.; Javoy-Agid, F.; Cooper, J.M.; Schapira, A.H. Mitochondrial defect in huntington's disease caudate nucleus. Ann. Neurol. 1996, 39, 385-389. [CrossRef] [PubMed]

206. Moreira, P.I.; Santos, M.S.; Oliveira, C.R. Alzheimer's disease: A lesson from mitochondrial dysfunction. Antioxid. Redox Signal. 2007, 9, 1621-1630. [CrossRef] [PubMed]

207. Swerdlow, R.H.; Khan, S.M. The alzheimer's disease mitochondrial cascade hypothesis: An update. Exp. Neurol. 2009, 218, 308-315. [CrossRef] [PubMed]

208. Gabuzda, D.; Busciglio, J.; Chen, L.B.; Matsudaira, P.; Yankner, B.A. Inhibition of energy metabolism alters the processing of amyloid precursor protein and induces a potentially amyloidogenic derivative. J. Biol. Chem. 1994, 269, 13623-13628. [PubMed]

209. Apelt, J.; Bigl, M.; Wunderlich, P.; Schliebs, R. Aging-related increase in oxidative stress correlates with developmental pattern of $\beta$-secretase activity and $\beta$-amyloid plaque formation in transgenic TG2576 mice with alzheimer-like pathology. Int. J. Dev. Neurosci. 2004, 22, 475-484. [CrossRef] [PubMed]

210. Hefti, F.; Goure, W.F.; Jerecic, J.; Iverson, K.S.; Walicke, P.A.; Krafft, G.A. The case for soluble A $\beta$ oligomers as a drug target in alzheimer's disease. Trends Pharmacol. Sci. 2013, 34, 261-266. [CrossRef] [PubMed]

211. Sanmartin, C.D.; Adasme, T.; Hidalgo, C.; Paula-Lima, A.C. The antioxidant $N$-acetylcysteine prevents the mitochondrial fragmentation induced by soluble amyloid- $\beta$ peptide oligomers. Neurodegener. Dis. 2012, 10, 34-37. [CrossRef] [PubMed]

212. Bush, A.I.; Masters, C.L.; Tanzi, R.E. Copper, $\beta$-amyloid, and alzheimer's disease: Tapping a sensitive connection. Proc. Natl. Acad. Sci. USA 2003, 100, 11193-11194. [CrossRef] [PubMed]

213. Ma, T.; Hoeffer, C.A.; Wong, H.; Massaad, C.A.; Zhou, P.; Iadecola, C.; Murphy, M.P.; Pautler, R.G.; Klann, E. Amyloid $\beta$-induced impairments in hippocampal synaptic plasticity are rescued by decreasing mitochondrial superoxide. J. Neurosci. 2011, 31, 5589-5595. [CrossRef] [PubMed]

214. Harrison, F.E.; Hosseini, A.H.; McDonald, M.P.; May, J.M. Vitamin C reduces spatial learning deficits in middle-aged and very old app/psen1 transgenic and wild-type mice. Pharmacol. Biochem. Behav. 2009, 93, 443-450. [CrossRef] [PubMed]

215. Kennard, J.A.; Harrison, F.E. Intravenous ascorbate improves spatial memory in middle-aged APP/PSEN1 and wild type mice. Behav. Brain Res. 2014, 264, 34-42. [CrossRef] [PubMed]

216. Murakami, K.; Murata, N.; Ozawa, Y.; Kinoshita, N.; Irie, K.; Shirasawa, T.; Shimizu, T. Vitamin C restores behavioral deficits and amyloid- $\beta$ oligomerization without affecting plaque formation in a mouse model of alzheimer's disease. J. Alzheimer's Dis. 2011, 26, 7-18.

217. Kook, S.Y.; Lee, K.M.; Kim, Y.; Cha, M.Y.; Kang, S.; Baik, S.H.; Lee, H.; Park, R.; Mook-Jung, I. High-dose of vitamin $C$ supplementation reduces amyloid plaque burden and ameliorates pathological changes in the brain of 5XFAD mice. Cell Death Dis. 2014, 5, e1083. [CrossRef] [PubMed]

218. Charlton, K.E.; Rabinowitz, T.L.; Geffen, L.N.; Dhansay, M.A. Lowered plasma vitamin C, but not vitamin e, concentrations in dementia patients. J. Nutr. Health Aging 2004, 8, 99-107. [PubMed]

219. Riviere, S.; Birlouez-Aragon, I.; Nourhashemi, F.; Vellas, B. Low plasma vitamin C in alzheimer patients despite an adequate diet. Int. J. Geriatr. Psychiatry 1998, 13, 749-754. [CrossRef]

220. Zandi, P.P.; Anthony, J.C.; Khachaturian, A.S.; Stone, S.V.; Gustafson, D.; Tschanz, J.T.; Norton, M.C.; Welsh-Bohmer, K.A.; Breitner, J.C.; Cache County Study, G. Reduced risk of alzheimer disease in users of antioxidant vitamin supplements: The cache county study. Arch. Neurol. 2004, 61, 82-88. [CrossRef] [PubMed]

221. DiFiglia, M. Excitotoxic injury of the neostriatum: A model for huntington's disease. Trends Neurosci. 1990, 13, 286-289. [CrossRef]

222. Twelvetrees, A.E.; Yuen, E.Y.; Arancibia-Carcamo, I.L.; MacAskill, A.F.; Rostaing, P.; Lumb, M.J.; Humbert, S.; Triller, A.; Saudou, F.; Yan, Z.; et al. Delivery of GABAARs to synapses is mediated by HAP1-KIF5 and disrupted by mutant huntingtin. Neuron 2010, 65, 53-65. [CrossRef] [PubMed]

223. Caviston, J.P.; Holzbaur, E.L. Huntingtin as an essential integrator of intracellular vesicular trafficking. Trends Cell Biol. 2009, 19, 147-155. [CrossRef] [PubMed] 
224. Bamford, K.A.; Caine, E.D.; Kido, D.K.; Cox, C.; Shoulson, I. A prospective evaluation of cognitive decline in early huntington's disease: Functional and radiographic correlates. Neurology 1995, 45, 1867-1873. [CrossRef] [PubMed]

225. Brandt, J.; Folstein, S.E.; Folstein, M.F. Differential cognitive impairment in alzheimer's disease and huntington's disease. Ann. Neurol. 1988, 23, 555-561. [CrossRef] [PubMed]

226. Shiwach, R. Psychopathology in huntington's disease patients. Acta Psychiatr. Scand. 1994, 90, $241-246$. [CrossRef] [PubMed]

227. Bruyn, G.W.; von Wolferen, W.J. Pathogenesis of huntington's chorea. Lancet 1973, 1, 1382. [CrossRef]

228. Hersch, S.M.; Gevorkian, S.; Marder, K.; Moskowitz, C.; Feigin, A.; Cox, M.; Como, P.; Zimmerman, C.; Lin, M.; Zhang, L.; et al. Creatine in huntington disease is safe, tolerable, bioavailable in brain and reduces serum 8OH2'dG. Neurology 2006, 66, 250-252. [CrossRef] [PubMed]

229. Browne, S.E.; Ferrante, R.J.; Beal, M.F. Oxidative stress in huntington's disease. Brain Pathol. 1999, 9, 147-163. [CrossRef] [PubMed]

230. Browne, S.E.; Beal, M.F. Oxidative damage in huntington's disease pathogenesis. Antioxid. Redox Signal. 2006, 8, 2061-2073. [CrossRef] [PubMed]

231. Sorolla, M.A.; Reverter-Branchat, G.; Tamarit, J.; Ferrer, I.; Ros, J.; Cabiscol, E. Proteomic and oxidative stress analysis in human brain samples of huntington disease. Free Radic. Biol. Med. 2008, 45, 667-678. [CrossRef] [PubMed]

232. Santamaria, A.; Perez-Severiano, F.; Rodriguez-Martinez, E.; Maldonado, P.D.; Pedraza-Chaverri, J.; Rios, C.; Segovia, J. Comparative analysis of superoxide dismutase activity between acute pharmacological models and a transgenic mouse model of huntington's disease. Neurochem. Res. 2001, 26, 419-424. [CrossRef] [PubMed]

233. Gines, S.; Seong, I.S.; Fossale, E.; Ivanova, E.; Trettel, F.; Gusella, J.F.; Wheeler, V.C.; Persichetti, F.; MacDonald, M.E. Specific progressive camp reduction implicates energy deficit in presymptomatic huntington's disease knock-in mice. Hum. Mol. Genet. 2003, 12, 497-508. [CrossRef] [PubMed]

234. Kuwert, T.; Lange, H.W.; Boecker, H.; Titz, H.; Herzog, H.; Aulich, A.; Wang, B.C.; Nayak, U.; Feinendegen, L.E. Striatal glucose consumption in chorea-free subjects at risk of huntington's disease. J. Neurol. 1993, 241, 31-36. [CrossRef] [PubMed]

235. Leenders, K.L.; Frackowiak, R.S.; Quinn, N.; Marsden, C.D. Brain energy metabolism and dopaminergic function in huntington's disease measured in vivo using positron emission tomography. Mov. Disord. 1986, 1, 69-77. [CrossRef] [PubMed]

236. Powers, W.J.; Videen, T.O.; Markham, J.; McGee-Minnich, L.; Antenor-Dorsey, J.V.; Hershey, T.; Perlmutter, J.S. Selective defect of in vivo glycolysis in early huntington's disease striatum. Proc. Natl. Acad. Sci. USA 2007, 104, 2945-2949. [CrossRef] [PubMed]

237. Benchoua, A.; Trioulier, Y.; Zala, D.; Gaillard, M.C.; Lefort, N.; Dufour, N.; Saudou, F.; Elalouf, J.M.; Hirsch, E.; Hantraye, P.; et al. Involvement of mitochondrial complex II defects in neuronal death produced by $N$-terminus fragment of mutated huntingtin. Mol. Biol. Cell 2006, 17, 1652-1663. [CrossRef] [PubMed]

238. Brennan, W.A., Jr.; Bird, E.D.; Aprille, J.R. Regional mitochondrial respiratory activity in huntington's disease brain. J. Neurochem. 1985, 44, 1948-1950. [CrossRef] [PubMed]

239. Browne, S.E. Mitochondria and huntington's disease pathogenesis: Insight from genetic and chemical models. Ann. N. Y. Acad. Sci. 2008, 1147, 358-382. [CrossRef] [PubMed]

240. Lim, D.; Fedrizzi, L.; Tartari, M.; Zuccato, C.; Cattaneo, E.; Brini, M.; Carafoli, E. Calcium homeostasis and mitochondrial dysfunction in striatal neurons of huntington disease. J. Biol. Chem. 2008, 283, 5780-5789. [CrossRef] [PubMed]

241. Milakovic, T.; Johnson, G.V. Mitochondrial respiration and ATP production are significantly impaired in striatal cells expressing mutant huntingtin. J. Biol. Chem. 2005, 280, 30773-30782. [CrossRef] [PubMed]

242. Tabrizi, S.J.; Cleeter, M.W.; Xuereb, J.; Taanman, J.W.; Cooper, J.M.; Schapira, A.H. Biochemical abnormalities and excitotoxicity in huntington's disease brain. Ann. Neurol. 1999, 45, 25-32. [CrossRef]

243. Damiano, M.; Galvan, L.; Deglon, N.; Brouillet, E. Mitochondria in huntington's disease. BBA Mol. Basis Dis. 2010, 1802, 52-61. [CrossRef] [PubMed]

244. Parker, W.D., Jr.; Boyson, S.J.; Luder, A.S.; Parks, J.K. Evidence for a defect in NADH: Ubiquinone oxidoreductase (complex I) in huntington's disease. Neurology 1990, 40, 1231-1234. [CrossRef] [PubMed] 
245. Brouillet, E.; Conde, F.; Beal, M.F.; Hantraye, P. Replicating huntington's disease phenotype in experimental animals. Prog. Neurobiol. 1999, 59, 427-468. [CrossRef]

246. Ruan, Q.; Lesort, M.; MacDonald, M.E.; Johnson, G.V. Striatal cells from mutant huntingtin knock-in mice are selectively vulnerable to mitochondrial complex II inhibitor-induced cell death through a non-apoptotic pathway. Hum. Mol. Genet. 2004, 13, 669-681. [CrossRef] [PubMed]

247. Choo, Y.S.; Johnson, G.V.; MacDonald, M.; Detloff, P.J.; Lesort, M. Mutant huntingtin directly increases susceptibility of mitochondria to the calcium-induced permeability transition and cytochrome $c$ release. Hum. Mol. Genet. 2004, 13, 1407-1420. [CrossRef] [PubMed]

248. Panov, A.V.; Gutekunst, C.A.; Leavitt, B.R.; Hayden, M.R.; Burke, J.R.; Strittmatter, W.J.; Greenamyre, J.T. Early mitochondrial calcium defects in huntington's disease are a direct effect of polyglutamines. Nat. Neurosci. 2002, 5, 731-736. [CrossRef] [PubMed]

249. Petrasch-Parwez, E.; Nguyen, H.P.; Lobbecke-Schumacher, M.; Habbes, H.W.; Wieczorek, S.; Riess, O.; Andres, K.H.; Dermietzel, R.; von Horsten, S. Cellular and subcellular localization of huntingtin [corrected] aggregates in the brain of a rat transgenic for huntington disease. J. Comp. Neurol. 2007, 501, 716-730. [CrossRef] [PubMed]

250. Cui, L.; Jeong, H.; Borovecki, F.; Parkhurst, C.N.; Tanese, N.; Krainc, D. Transcriptional repression of PGC- $1 \alpha$ by mutant huntingtin leads to mitochondrial dysfunction and neurodegeneration. Cell 2006, 127, 59-69. [CrossRef] [PubMed]

251. McGill, J.K.; Beal, M.F. PGC-1 $\alpha$, a new therapeutic target in huntington's disease? Cell 2006, 127, 465-468. [CrossRef] [PubMed]

252. St-Pierre, J.; Drori, S.; Uldry, M.; Silvaggi, J.M.; Rhee, J.; Jager, S.; Handschin, C.; Zheng, K.; Lin, J.; Yang, W.; et al. Suppression of reactive oxygen species and neurodegeneration by the PGC-1 transcriptional coactivators. Cell 2006, 127, 397-408. [CrossRef] [PubMed]

253. Rebec, G.V.; Barton, S.J.; Marseilles, A.M.; Collins, K. Ascorbate treatment attenuates the huntington behavioral phenotype in mice. Neuroreport 2003, 14, 1263-1265. [CrossRef] [PubMed]

254. Dorner, J.L.; Miller, B.R.; Klein, E.L.; Murphy-Nakhnikian, A.; Andrews, R.L.; Barton, S.J.; Rebec, G.V. Corticostriatal dysfunction underlies diminished striatal ascorbate release in the R6/2 mouse model of huntington's disease. Brain Res. 2009, 1290, 111-120. [CrossRef] [PubMed]

255. Rebec, G.V.; Conroy, S.K.; Barton, S.J. Hyperactive striatal neurons in symptomatic huntington R6/2 mice: Variations with behavioral state and repeated ascorbate treatment. Neuroscience 2006, 137, 327-336. [CrossRef] [PubMed]

256. Hirsch, E.C.; Jenner, P.; Przedborski, S. Pathogenesis of parkinson's disease. Mov. Disord. 2013, $28,24-30$. [CrossRef] [PubMed]

257. Braak, H.; del Tredici, K.; Rub, U.; de Vos, R.A.; Jansen Steur, E.N.; Braak, E. Staging of brain pathology related to sporadic parkinson's disease. Neurobiol. Aging 2003, 24, 197-211. [CrossRef]

258. Booij, J.; Tissingh, G.; Boer, G.J.; Speelman, J.D.; Stoof, J.C.; Janssen, A.G.; Wolters, E.C.; van Royen, E.A. [123I]FP-CIT SPECT shows a pronounced decline of striatal dopamine transporter labelling in early and advanced parkinson's disease. J. Neurol. Neurosurg. Psychiatry 1997, 62, 133-140. [CrossRef] [PubMed]

259. Iranzo, A.; Lomena, F.; Stockner, H.; Valldeoriola, F.; Vilaseca, I.; Salamero, M.; Molinuevo, J.L.; Serradell, M.; Duch, J.; Pavia, J.; et al. Decreased striatal dopamine transporter uptake and substantia nigra hyperechogenicity as risk markers of synucleinopathy in patients with idiopathic rapid-eye-movement sleep behaviour disorder: A prospective study [corrected]. Lancet Neurol. 2010, 9, 1070-1077. [CrossRef]

260. Kaufman, M.J.; Madras, B.K. Severe depletion of cocaine recognition sites associated with the dopamine transporter in parkinson's-diseased striatum. Synapse 1991, 9, 43-49. [CrossRef] [PubMed]

261. Biskup, S.; Gerlach, M.; Kupsch, A.; Reichmann, H.; Riederer, P.; Vieregge, P.; Wullner, U.; Gasser, T. Genes associated with parkinson syndrome. J. Neurol. 2008, 255 5, 8-17. [CrossRef] [PubMed]

262. Schapira, A.H. Mitochondrial dysfunction in neurodegenerative diseases. Neurochem. Res. 2008, 33, 2502-2509. [CrossRef] [PubMed]

263. Henchcliffe, C.; Beal, M.F. Mitochondrial biology and oxidative stress in parkinson disease pathogenesis. Nat. Clin. Pract. Neurol. 2008, 4, 600-609. [CrossRef] [PubMed]

264. Bindoff, L.A.; Birch-Machin, M.; Cartlidge, N.E.; Parker, W.D., Jr.; Turnbull, D.M. Mitochondrial function in Parkinson's disease. Lancet 1989, 2, 49. [CrossRef] 
265. Mizuno, Y.; Ohta, S.; Tanaka, M.; Takamiya, S.; Suzuki, K.; Sato, T.; Oya, H.; Ozawa, T.; Kagawa, Y. Deficiencies in complex I subunits of the respiratory chain in parkinson's disease. Biochem. Biophys. Res. Commun. 1989, 163, 1450-1455. [CrossRef]

266. Schapira, A.H.; Cooper, J.M.; Dexter, D.; Jenner, P.; Clark, J.B.; Marsden, C.D. Mitochondrial complex I deficiency in parkinson's disease. Lancet 1989, 1, 1269. [CrossRef]

267. Xiang, W.; Schlachetzki, J.C.; Helling, S.; Bussmann, J.C.; Berlinghof, M.; Schaffer, T.E.; Marcus, K.; Winkler, J.; Klucken, J.; Becker, C.M. Oxidative stress-induced posttranslational modifications of $\alpha$-synuclein: Specific modification of $\alpha$-synuclein by 4-hydroxy-2-nonenal increases dopaminergic toxicity. Mol. Cell. Neurosci. 2013, 54, 71-83. [CrossRef] [PubMed]

268. Khan, S.; Jyoti, S.; Naz, F.; Shakya, B.; Rahul; Afzal, M.; Siddique, Y.H. Effect of L-ascorbic acid on the climbing ability and protein levels in the brain of drosophila model of Parkinson's disease. Int. J. Neurosci. 2012, 122, 704-709. [CrossRef] [PubMed]

269. Ballaz, S.; Morales, I.; Rodriguez, M.; Obeso, J.A. Ascorbate prevents cell death from prolonged exposure to glutamate in an in vitro model of human dopaminergic neurons. J. Neurosci. Res. 2013, 91, 1609-1617. [CrossRef] [PubMed]

270. Foy, C.J.; Passmore, A.P.; Vahidassr, M.D.; Young, I.S.; Lawson, J.T. Plasma chain-breaking antioxidants in Alzheimer's disease, vascular dementia and parkinson's disease. QJM 1999, 92, 39-45. [CrossRef] [PubMed]

271. Sohmiya, M.; Tanaka, M.; Tak, N.W.; Yanagisawa, M.; Tanino, Y.; Suzuki, Y.; Okamoto, K.; Yamamoto, Y. Redox status of plasma coenzyme Q10 indicates elevated systemic oxidative stress in parkinson's disease. J. Neurol. Sci. 2004, 223, 161-166. [CrossRef] [PubMed]

272. Ide, K.; Yamada, H.; Umegaki, K.; Mizuno, K.; Kawakami, N.; Hagiwara, Y.; Matsumoto, M.; Yoshida, H.; Kim, K.; Shiosaki, E.; et al. Lymphocyte vitamin C levels as potential biomarker for progression of parkinson's disease. Nutrition 2015, 31, 406-408. [CrossRef] [PubMed]

273. Fitzgerald, K.C.; O’Reilly, E.J.; Fondell, E.; Falcone, G.J.; McCullough, M.L.; Park, Y.; Kolonel, L.N.; Ascherio, A. Intakes of vitamin $\mathrm{C}$ and carotenoids and risk of amyotrophic lateral sclerosis: Pooled results from 5 cohort studies. Ann. Neurol. 2013, 73, 236-245. [PubMed]

(C) 2015 by the authors; licensee MDPI, Basel, Switzerland. This article is an open access article distributed under the terms and conditions of the Creative Commons by Attribution (CC-BY) license (http://creativecommons.org/licenses/by/4.0/). 